IZA DP No. 5646

Parental Education, Grade Attainment and Earnings Expectations among University Students

Liam Delaney

Colm Harmon

Cathy Redmond

April 2011 


\title{
Parental Education, Grade Attainment and Earnings Expectations among University Students
}

\author{
Liam Delaney \\ University College Dublin \\ Colm Harmon \\ University College Dublin, \\ ANU Canberra and IZA \\ Cathy Redmond \\ University College London
}

\author{
Discussion Paper No. 5646 \\ April 2011 \\ IZA \\ P.O. Box 7240 \\ 53072 Bonn \\ Germany \\ Phone: +49-228-3894-0 \\ Fax: +49-228-3894-180 \\ E-mail: iza@iza.org
}

\begin{abstract}
Any opinions expressed here are those of the author(s) and not those of IZA. Research published in this series may include views on policy, but the institute itself takes no institutional policy positions.

The Institute for the Study of Labor (IZA) in Bonn is a local and virtual international research center and a place of communication between science, politics and business. IZA is an independent nonprofit organization supported by Deutsche Post Foundation. The center is associated with the University of Bonn and offers a stimulating research environment through its international network, workshops and conferences, data service, project support, research visits and doctoral program. IZA engages in (i) original and internationally competitive research in all fields of labor economics, (ii) development of policy concepts, and (iii) dissemination of research results and concepts to the interested public.
\end{abstract}

IZA Discussion Papers often represent preliminary work and are circulated to encourage discussion. Citation of such a paper should account for its provisional character. A revised version may be available directly from the author. 


\section{ABSTRACT}

\section{Parental Education, Grade Attainment and Earnings Expectations among University Students ${ }^{*}$}

While there is an extensive literature on intergenerational transmission of economic outcomes (education, health and income for example), many of the pathways through which these outcomes are transmitted are not as well understood. We address this deficit by analysing the relationship between socio-economic status and child outcomes in university, based on a rich and unique dataset of university students. While large socio-economic differences in academic performance exist at the point of entry into university, these differences are substantially narrowed during the period of study. Importantly, the differences across socio-economic backgrounds in university grade attainment for female students is explained by intermediating variables such as personality, risk attitudes and time preferences, and subject/college choices. However, for male students, we explain less than half of the socio-economic gradient through these same pathways. Despite the weakening socio-economic effect in grade attainment, a key finding is that large socio-economic differentials in the earnings expectations of university students persist, even when controlling for grades in addition to our rich set of controls. Our findings pose a sizable challenge for policy in this area as they suggest that equalising educational outcomes may not translate into equal labour market outcomes.

JEL Classification: $\quad$ 121, J62, C81

Keywords: socio-economic status, education, inequality, discrimination

Corresponding author:

Colm Harmon

UCD Geary Institute

University College Dublin

Belfield, Dublin 4

Ireland

E-mail: colm.harmon@ucd.ie

\footnotetext{
* The authors thank the research team on the IUS study - Mary Doyle, Sarah Gubbins, Mark McGovern and Martin Ryan. The comments of an anonymous referee to earlier drafts of this paper, and also of Matt Dickson of the University of Bristol, greatly improved the exposition of this paper. Thanks also to Dr Conor O'Carroll at the Irish Universities Association for his support, and to James Smith, Keith O'Hara and Seamus McManus for useful comments. Cathy Redmond is a graduate student in Economics at University College London. Funding for the IUS is provided under the auspices of the Strategic Innovation Fund of the Irish Higher Education Authority. An earlier version of this paper was circulated as a UCD Geary Institute working paper. The usual disclaimer applies.
} 


\section{Introduction}

The intergenerational transmission of education and income is a key concern of education economists and policymakers, with a substantial body of literature demonstrating high correlations between parental education and child education (Black and Devereux, 2010; Ermisch and Del Bono, 2010; Machin and Murphy, 2010). For example, the elasticity of child education with respect to parental education has been shown to be of the order of 0.3 to 0.5 in a large recent meta-analysis (Hertz et al., 2007). However, these estimates do not examine the extent to which parental education influences grade performance within education attainment levels,or the expectedeconomic return to education. In the case of higher education, looking at grade performance is important as it allows us to examine not only whether students from different socioeconomic backgrounds participate differentially in higher education but also what outcomes they attain once they participate. Similarly, examining earnings expectations among college participants allows us to examine whether students from different socioeconomic backgrounds, conditional on both participation and performance, have differing apriori expectations of how their qualifications will translate into earnings.

To understand further the role of socioeconomic status in outcomes among higher education participants,this paper investigates the interaction between socio-economic status,(as measured by parental education levels), and higher education from matriculation to graduation. We provide new estimates of the magnitude of the intergenerational relationship between parental education and both grade performance in university and the expected return from university education. Furthermore, we go further than much current research in examining the channels through which these transmissions occur by estimating detailed decompositions of these intergenerational relationships. Along with standard demographic variables, our decomposition allows for intergenerational transmission through choice of institute, subject choice, pre-university academic performance and a wide range of personality 
traits. There is a growing literature incorporating character controls into economic models (Borghans et al., 2008), moreover, there is evidence that personality traits and preference parameters are transmitted from parent to child (Dohmen et al., 2006; Goldsmith et al., 1994). In our decomposition analysis we contribute to this literature by examining whether personality traits constitute one of the pathways through which intergenerational transmission of education outcomes occurs.

Using data from a study across all seven Irish universities designed and implemented by the authors, we examine whether university entry mechanisms (where secondary (high) school exam results are used to allocate places) are predictive of university performance controlling for socio-economic status (SES), allowing us to determine whether the university admission system is based upon academic aptitude or the ability of wealthy families to confer educational advantage onto their children (Sackett et al., 2009). Secondly, weexamine the magnitude of the socio-economic attainment gaps in university, and the extent to which these differentials are mitigated through choice of institute, subject choice, prior academic attainment or character traits. ${ }^{1}$ We analyse the extent to which the university system itself contributes to increasing (or decreasing) socioeconomic attainment gaps among college students by comparing the attainment gap at entry to college attainment differences. Thirdly, a large body of literature shows that earnings expectations can both be meaningfully elicited (e.g. Dominitz and Manski, 1996) and are predictive of later salaries (Webbinkand Hartog, 2004) with little evidence of any systematic bias, but there is a socioeconomic gradient in these earnings expectations and in the perceived economic returns to education (Smith and Powell, 1990).Weexamine in detail whether this socio-economic gradient in expectations of the returns from education can be explained through pathways such as choice of institute, subject choice, grade attainment in university or character traits.

\footnotetext{
${ }^{1}$ Also, recent papers by Walker \& Zhu (2011) (UK data) and Kelly, O’Connell \& Smyth (2010) (Irish Data) analyse heterogeneity in the return to university education by gender, subject and degree class.
} 
The rest of the paper is organized as follows. Section 2 contextualizes the Irish education system. Section 3 outlines details of the data used in the study and provides information on various measures used in the analysis. Section 4 outlines the econometric methodology used and reports the findings from the three key research questions outlined above and Section 5 concludes.

\section{Context - Irish Education System in Brief}

The Irish education system is split into primary education (elementary), secondary education (high-school) and tertiary (higher \& further) education. Primary and secondary education is provided by the State, and while some students attend private fee paying schools the vast majority attend state funded schools. Students typically attend primary school from the age of 4 to 12 , and attend secondary school from the age of 12 to 18 . While there is a minimum school leaving age of 16 (and an intermediate examination taken at around this age known as the Junior Certificate, akin to the GCSE/O-Level examination in the United Kingdom), for the majority of the age cohort (84.7\%), the culmination of secondary education is a set of national exams called the Leaving Certificate which are taken in the final year of secondary school. ${ }^{2}$

Seven universities and 15 institutes of technology provide the bulk of tertiary education in Ireland. ${ }^{3,4}$ Following reforms introduced in 1995, undergraduate education is funded by the State so there is no direct tuition fee for participants. ${ }^{5}$ The admission rate to higher education in Ireland in 2004 was 55 percent, and, despite the reforms that abolished direct tuition fees, significant socio-economic gradients in participation exist (O’Connell et al., 2006; Denny, 2010). There is some evidence of a softening of this gradient - in 1998, some 23 percent of higher education participants came from semi-skilled/unskilled

\footnotetext{
${ }^{2}$ Adjusted retention estimate of 2001 Junior Cycle intake cohort (Department of Education and Skills, 2009).

${ }^{3}$ Dublin City University, National University of Ireland Galway, National University of Ireland Maynooth, Trinity College Dublin, University College Cork, University College Dublin and the University of Limerick.

${ }^{4}$ There are also seven teacher-training colleges, one pontifical college, one college of art and design and one college that provides business related qualifications.

${ }^{5}$ However, there is a 'Student Services Fee' (or registration fee) of up to $€ 1,500$ paid by the student each year.
} 
background, whereas this increased to 40 percent by 2004 (O’Connell et al., 2006). See Figure 1 below. Much of this participation, however, reflects an increase in the number of places in institutes of technology (which have a much broader socio-economic representation).

\section{FIGURE 1 HERE}

Places on courses in all higher education institutions are blind allocatedbased on Leaving Certificate results and managed by an independent agency (the Central Applications Office). Unlike many admissions systems, such as the US and UK, there is no pre-screening based on expected results or other extra-curricular activities (such as community engagement, sporting achievement etc), with the exception of a small number of courses in areas such as fine art where a portfolio of activity is taken into account. Students apply for up to ten university, institute of technology or college degree coursesin order of preference.They may also apply separately for up to ten sub-degree (diploma/certificate) courses, also in order of preference.

Typically, students take seven subjects in the Leaving Certificate, and the grades are converted into points (e.g. A1 = 100 points, $\mathrm{A} 2=90$ points, etc.). The top six subjects are summed resulting in a Leaving Certificate 'point score' of between 0 and 600. Each degree, diploma and certificate course has a point threshold which is a function of the number of places available and the achieved grades of the applicants - specifically, a course with $N$ places would have a points threshold equal to the actual score of the $N^{\text {th }}$ applicant (ordered from highest scoring to lowest scoring) for the particular course of study. If a student achieves above the points threshold for their first choice they are offered this course. If they do not get enough points for their first choice they are offered the next choice on their list for which they do have enough points. The preference ordering is adhered to strictly - a student can move up the list (i.e. move from their second to first preference course if a place becomes 
available) but never downwards. ${ }^{6}$ Gormley and Murphy (2006) provide a comprehensive overview of this system, in particular the nature of the points system.

\section{Data and Measurement}

Our analysis is based on two surveys of students registered at all seven Irish universities that were designed and conducted by the authors on behalf of the Irish University Association as part of the Irish Universities Study (IUS). ${ }^{7}$ The earlier round of the survey (IUS1), which was carried out between January and June 2009, is used to analyse student's earnings expectations, given the rich battery of personality measures available in that round. The more recent round of the survey (IUS2), which was carried out between December 2009 and April 2010, is used to estimate the relationship between grade attainment in university and socioeconomic status because this round of the survey contained more detailed information on grade attainment in university, however it had less detailed personality measurement.

In both rounds, from the total university student undergraduate population in Ireland of approximately 73000 students, 22 percent (16000 students) were randomly sampled. The response rates of the random samples were 13.4 percent and 18.7 respectively in IUS1 and IUS2. In addition, 3000 undergraduate students who had responded to earlier survey roundswere invited to participate in the more recent round of the survey (IUS2). The response rate for this follow-up cohort was 34.1 percent. $^{8}$

Focus groups conducted in the universities indicated that many students who were selected into the survey do not actively use their university email account. In addition, some students admitted to routinelynot opening e-mails from the university plenary (who contacted them to request participation) or complained of survey saturation. Therefore, we believe our 'true' response rate is somewhat higher than the actual rate (if we base the rate on the sample

\footnotetext{
${ }^{6}$ If a student applies for both Level 8 and Level 6/Level 7 courses they can receive two offers. There are some alternative entry routes in university, such as access programmes or mature student entry.

${ }^{7}$ The two institutions in Northern Ireland (Queen's University of Belfast and the University of Ulster) are not included in our sample.

${ }^{8}$ Full details on the IUS, including issues on sampling design etc, are available at www.iua.ie
} 
actually successfully contacted). Nevertheless there is a possibility of sampling bias because the students who actually received the survey and made the choice to participate may come from non-random backgrounds. In order to explore the potential size and impact of these sources of sampling bias we compared observables in the survey to that of population statistics (gender, college and main subject area). Table 1 shows how official Higher Education Authority (HEA) data from 2008/2009 compares to the IUS data. The distribution is largely similar; however there are some discrepancies in the response rate across universities (which focus groups indicated was due to differences in university email address usage rates across institutions). However, the extent to which the sample statistics mirror HEA official statistics provide evidence of the robustness and representativeness of our data.

\section{TABLE 1 HERE}

The sample used was restricted to Irish full-time undergraduate students who were in fourth year or below and who were between the ages of seventeen and thirty to minimize unobserved heterogeneity. This resulted in a sample size of 2472 in IUS1 and 2669 in IUS2. ${ }^{9}$ Table 2 outlines the descriptive statistics for the key variables used in the paper. The left hand side of Table 2 outlines the descriptive statistics for the restricted IUS sample, whilst the right hand side outlines the key descriptive statistics when missing values for all variables are dropped (i.e. the estimating sample). As can be seen there is little difference between these two sets of statistics, suggesting that following our initial sample restrictions, missing data are randomly distributed across the sample.

\section{TABLE 2 HERE}

\footnotetext{
${ }^{9}$ Details on the sample selection issues for the two datasets are as follows: IUS1 (IUS2) - Total observations: 4679 (4781); dropping international students - 3873 (4185); restricting to only full-time undergraduate students in year four or below of study- 2582 (2847); and, restricting the sample to those between aged 17 and $30-2472$ (2669).
} 
Leaving Certificate points are 468 in both the estimating sample of IUS1 and IUS2. Self-reported average university grade is our measure of university performance. The question on grade attainment from IUS2 is: “What was your average result last year in percent?"For those students who did not answer this question (e.g. $1^{\text {st }}$ year students) the dependent variable is expected grade attainment in the current year based on the following question: "What grade do you expect to obtain this year?” In the estimating sample of IUS2 (used to estimate the relationship between grade and socio-economic status) this ranges from 0 to 98 with a mean of 64.76 and a standard deviation of $10.55 .^{10,11,12}$ In our analysis we also test how earnings expectations are transmitted from parents to students. Students were asked to report both their short ("What is the annual salary in Euro that you expect to earn in your first job after graduation?") and long run ("What is the maximum annual salary in Euro that you expect to earn over your career?)earnings expectations in current prices. Possible outcomes were presented to the respondent in bands of $€ 10,000$ for short run expectations and in bands of $€ 20,000$ for long run expectations - short run options ranged from $€ 0$ to greater than $€ 100,000$, and long run options ranged from $€ 0$ to greater than $€ 200,000$. In the estimating sample, the mean (calculated by taking a linear approximation through the mid-point of the bands) of the short run earnings expectations is $€ 32,104$ and the mean of the long-run earnings expectations is $€ 103,838$.

Parental education is reported in the data in terms of qualifications attained. We convert this into years of education by approximating the years of education necessary to obtain the reported qualification, e.g. primary school education is considered equivalent to

\footnotetext{
${ }^{10}$ We tested for sensitivity in excluding respondents who reported expected rather than realised grade. Results are quantitatively similar and the main grade decomposition excluding these respondents is shown in Appendix 3 Table A3 -1.

${ }^{11}$ Our data does not provide information on drop-out patterns in university. However, any gradients or differentials reported in this study are downwards biased by drop-outs if it is predominantly poorly performing, low SES students who are dropping out of university.

${ }^{12}$ Grade attainment is also reported in data set 2 , and is used as a control variable in the earnings expectations analysis. Grade was reported either on a A+, A , A-, B+ etc. scale or a $1^{\text {st }}$, 2:1, 2:2, etc. scale and was converted to a single 4 point grade scale.
} 
eight years of completed education. This variable ranges from eight years of education to 19 years of education (for completing a $\mathrm{PhD}$ ). In most of our analysis, paternal and maternal years of completed education are summed to provide a single measure. The distribution of parental education is shown in Figure 2 (drawn from IUS2).

\section{FIGURE 2 HERE}

Key to this paper is the availability of a number of well-validated and widely used measures of personality and preferences (see Borghans et al. (2008) for a review). Risk willingness was measured by asking students to report, on a scale of $0-10$, how willing they were to take risks in general, where higher values indicate higher risk willingness. Dohmen et al. (2005) provide experimental evidence that this measure of risk willingness is predictive of risk-taking behaviour, and that it outperforms other measures of risk preferences. Mean risk willingness is 6.01 in IUS2 and 6.47 in IUS1. In our analysis we also control for the future orientation of students. This was measured by using a subset of the questions from the Consideration of Future Consequences (CFC) scale (Strathman et al., 1994 - for question wording see Appendix 1). Students responded to four questions relating to how they think about the future, and reported on a five-point scale. These four responses are summed, yielding a variable that ranges between 4 and 20 with higher values indicating higher levels of future orientation. The CFC variable has a mean of 13.72 in IUS2 and 13.53 in IUS1. Finally, in the earnings expectations data set (IUS1), students were asked the Ten Item Personality Inventory (Gosling et al., 2003), a shortened version of the Big Five Inventory (BFI) personality scale - see Appendix 1 for question wording. ${ }^{13}$ Through ten questions, the TIPI scale measures the following five personality traits; extraversion, agreeableness, conscientiousness, neuroticism and openness on a scale of between 2 and 14. The mean

\footnotetext{
${ }^{13}$ Gosling et al. (2003) test the TIPI, and found that this personality scale performs well in terms of convergent and discriminate correlations with the BFI, test-retest reliability and external correlates.The Big Five Inventory personality scale was developed by a number of researchers including Allport\&Odbert (1936), TupesandChristal (1961), Norman (1963) and Goldberg (1981).
} 
values of these five traits were extraversion (9.28); agreeableness (6.21); conscientiousness (10.23); neuroticism (6.68); and openness (10.77).

\section{Model and Results}

Our basic model of the impact of parental background on the universityoutcomes of their children is:

$P_{i}=\alpha_{i}+\beta S_{i}+\omega L C_{i}+\mathbf{E}_{i} \gamma+\mathbf{X}_{i} \varphi+\varepsilon_{i}$

where $P$ is our measure of student outcome (performance in their degree programme or, in later specifications, their expectation of future income). This is a function ofparental SES (S); prior educational attainment measured by performance in the Leaving Certificate $(L C)$; $\mathbf{E}$, an (i x j) matrix of characteristics of the institution and course attended (for example, year of study, subject and college choice); and $\mathbf{X}$, an (i x k) matrix of characteristics of the student (gender, age, personality measures, etc).

In much of the analysis we report the results in the form of decompositions. This follows a long tradition in the empirical literature, notably work by Oaxaca (1973) and Blinder (1973).We follow the process outlined by Bowles \&Gintis (2002), who decompose intergenerational income correlation into the direct and indirect effects of parental income on child income. The indirect effect is the proportion of the total effect that is transmitted through intermediating variables (e.g. education choices or personality traits). The direct effect is the remainder of the total effect that can not be explained by intermediating variables. This approach is based upon the total derivative formula;

$$
\begin{aligned}
& y=f\left(z, x_{1}, x_{2}, \ldots, x_{m}\right) \\
& \frac{d y}{d z}=\frac{\delta y}{\delta z}+\sum_{j} \frac{\delta y}{\delta x_{j}} \frac{d x_{j}}{d z}
\end{aligned}
$$

where $=1,2 . . \mathrm{m}$. In this formulation, the total effect $d y / d z$ (the total derivative of $y$ with respect to $\mathrm{z}$ ) is made up of a direct effect, $\delta y / \delta z$ (the partial derivative of $y$ with respect to $z$ ), 
and an indirect effect, $\Sigma_{j} \delta y / \delta x_{j}{ }^{*}\left(d x_{j} / d z\right)$, the partial derivatives of $y$ with respect to $x_{j}$ multiplied by the derivative of $x_{j}$ with respect to $z$ summed.

We can use this approach to decompose the transmission of SES (measured by parental education) to grade attainment and earnings expectations into a direct effect and an indirect effect. Applying the formulation in (2b) to (1), and suppressing individual subscripts for ease of notation, gives

$$
\frac{d P}{d S}=\frac{\delta P}{\delta S}+\left(\sum_{j} \frac{\delta P}{\delta E_{j}} \frac{d E_{j}}{d S}+\sum_{k} \frac{\delta P}{\delta X_{k}} \frac{d X_{k}}{d S}\right),
$$

which decomposes the transmission of parental education to child outcomes into a direct component, and an indirect component from each of the $j$ education variables and the $k$ individual characteristics. If parental education is correlated with education variables (such as subject or college choice), and/or individual characteristics of the student (such as risk preferences, future orientation or personality), and if these factorspredict child outcomes, then parental education will have an indirect effectthrough these variables. To construct confidence intervals around the direct and indirect estimates, we use bootstrapped, biascorrected standard errors, as recommended in the literature (Shrout and Bolger, 2002). ${ }^{14}$

\section{INSERT TABLE 3}

Based on (1), Table 3 displays the results of an OLS regression of university grades on Leaving Certificate points, gender and age. As can be seen, Leaving Certificate points are highly significant (p-value $<0.01$ ). On average, an extra 100 Leaving Certificate points increase university grade by approximately 3 percentage points. As outlined above, if the relationship between Leaving Certificate performance and grade attainment in universityis robust to the addition of SES controls, then this is an indication that the current admissions system is based upon academic aptitude rather than simply being a reflection of socioeconomic status. As can be seen in column 2 of Table 3, the relationship between university

\footnotetext{
${ }^{14}$ Bias-corrected bootstrapping with 2000 replications was used in the analysis
} 
grade and Leaving Certificate points is robust to the addition of SES controls. Controlling for combined parental education has very little effect on the Leaving Certificate coefficient, in fact the coefficient on Leaving Certificate point increases (0.031 compared to 0.035), and the coefficient remains highly significant (p-value $<0.01$ ), suggesting that parental SES does not explain the predictive power of entrance scores on college grade attainment.

\section{INSERT TABLE 4}

Turning to the impact of parental education on university grades, the output in Table 4 shows a statistically significant but modest coefficient. ${ }^{15} \mathrm{An}$ additional year of parental education increases gradeon average by 0.10 of a percentage point, which, while statistically significant (p-value $<0.1$ ), is a small effect. However, the relationship between parental education and grade performance in university is much stronger for male students (column 2) with an additional year of parental education associated with an increase of 0.22 of a percentage point for males ( $\mathrm{p}$-value $<0.05$ ), but only 0.03 of a percentage point increase for females, which is statistically insignificant. This table also shows the decomposition of the differential into an explained (indirect) and an unexplained (direct) component. For the pooled group of students, 82 percent of the differential is explained by controlling for demographics (age and gender), education variables (year of study, college, subject and Leaving Certificate points) and character traits (risk preferences and CFC). The most important variable in explaining the differential is Leaving Certificate points which is highly significant (p-value $<0.01$ ) and explains fully the education gradient, with high SES students even scoring lower than one would predict relative to low SES students given their starting grades.

While high SES students perform better in the Leaving Certificate, and Leaving Certificate points are an important determinant of grade attainment in university (i.e. the

\footnotetext{
${ }^{15}$ Partial derivatives corresponding to Table 4 are shown in Table A2-1 of the Appendix, total derivatives are shown in Table A2-2.
} 
partial derivative of Leaving Certificate points with respect to grade attainment is positive), college and subject choice actually favour low SES students in the sense that low SES students are studying at colleges and are choosing subjects that, all else being equal, would give them higher grades than high SES students. ${ }^{16}$ Demographics also favour low SES students, since the partial derivatives of gender and age with respect to grade are both positive, and low SES students are more likely to be female and older. Finally, year of study and future orientation do not make a large contribution in explaining the differential (they explain $1 \%$ and $5 \%$ of the pooled differential respectively and neither is significant).

In columns 2 and 3 we analyse the decomposition separately for male and female students. For male students, less than half (43\%) of the differential is explained by the control variables, whereas for females the total differential is explained. In fact, females actually experience a negative direct (but insignificant) intergenerational transmission of grade attainment (-0.036; p-value $>0.1)$ when controlling for this set of variables (i.e. controlling for these variables, higher SES female students are performing worse in university).

\section{INSERT TABLE 5}

In Table 5, the transmission of grade attainment is examined separately for maternal and paternal education.A similar picture emerges, with a large direct transmission from both maternal and paternal education to grade attainment for males ( 0.22 and 0.12 respectively, although neither are statistically significant), but not for females (-0.06 and -0.01 respectively, again, neither are significant). For male students, the direct effect of maternal education is nearly twice as large as the direct effect of paternal education. We also decompose the grade differential using maximum parental education, a specification which allows for the inclusion

\footnotetext{
${ }^{16}$ Age contributes $-21 \%$ (p-value $<0.01$ ) to the differential and gender contributes $-1 \%$ but is statistically insignificant (p-value $>0.1)$ ). Risk willingness also favours low SES students (contributes $-10 \%$ (p-value < 0.05 ) to the pooled differential), since high SES students have higher risk preferences, and risk preferences have a negative partial derivative with respect to grade.
} 
of one-parent families. This decomposition yields quantitatively similar results and is shown in the Appendix 2 (Table A2-3).

\section{INSERT TABLE 6}

Table 6 compares the socio-economic gradient in university with the socio-economic gradient in entry-level scores (Leaving Certificate points). The standardized SES coefficient from the model of Leaving Certificate pointsis 0.06 (p-value $<0.01$ ) and the corresponding figure for the regression of university attainment is 0.01 (p-value $<0.1$ ), indicating that the SES gradient in secondary school is approximately 6 times greater than the gradient that exists in university, for the group of students who matriculate. When this is estimated separately for males and females, the dissipation of the SES gradient is much larger for females. The magnitude of the male gradient in secondary school is three times larger than the equivalent gradient in university, whereas the female gradient is eighteen times larger at secondary school than in university. These results imply that the SES gradient in academic performance dissipates to a large extent in university, particularly for female students. ${ }^{17}$

\section{INSERT TABLE 7}

Table 7 decomposes the relationship between parental education and short-run earnings expectations for the full sample as well as separately for males and females. ${ }^{18}$ Parental education has a significant and substantial total effect on both short-run and long-run earnings expectations. An additional year of parental education increases short run earnings expectations on average by $€ 188$ (p-value $<0.01$ ). The magnitude of the total impact of an additional year of parental education on short run earnings expectations is similar for males and females, although it is not statistically significant for males (an

\footnotetext{
${ }^{17}$ In absolute terms, on average, an additional year of parental education is associated with an extra 4.6 Leaving Certificate points, and $0.10 \%$ higher university grade. For males, an additional year of parental education is associated with 4.7 extra Leaving Certificate points and $0.22 \%$ higher university grade. The corresponding figures for females are 4.5 Leaving Certificate points and $0.03 \%$ higher university grade.

${ }_{18}$ Partial derivatives corresponding to Table 7 are shown in Table A2-4 of the Appendix, and total derivatives in Table A2-5
} 
additional year of parental education is associated with $€ 142$ (p-value $>0.1)$ and $€ 190$ (pvalue < 0.05) higher short run earnings expectations for male and female students respectively).

The vast majority of the socioeconomic gradient (100\% in the pooled decomposition; p-value < 0.01) is explainable by the intermediating variables. As in the grade attainment decomposition, the most important factor in explaining the differential is Leaving Certificate points (explains $60 \%$ of the pooled differential; p-value $<0.01$ ). This is due to the positive partial derivative of Leaving Certificate points with respect to short run earnings expectations, and the positive association between SES and Leaving Certificate performance. College and subject choice are also important, but in contrast to the grade decomposition, these intermediate variables now positively contribute $16 \%$ to explaining the differential, (p-value > 0.1), although the estimate is not statistically significant. Other significant intermediate variables are gender, age and risk preferences. While gender and risk preferences help explain the socio-economic differential in earnings expectations (contributing 8\%; p-value < 0.1 and 8\%; p-value < 0.05 respectively), age favours low SES students $(-6 \%$; p-value $<0.1)$. The five different personality measures contribute differently to the differential, but none are statistically significant (extraversion $7 \%$; agreeableness 2\%; conscientiousness $-5 \%$; neuroticism 1\%; openness $0 \%$ ). Future orientation does not contribute towards explaining the SES differential in short-run earnings expectations ( $0 \%$; p-value $>0.1)$. Interestingly, grade attainment does not significantly contribute towards explaining the SES short-run earnings expectations (1\%; p-value $>0.1)$.

\section{INSERT TABLE 8}

Table 8 shows this decomposition separately for maternal and paternal education, but the results give the same quantitative conclusions. Maternal and paternal education increase short-run earnings expectations for male students, although the estimates are not statistically 
significant (€206; p-value $>0.1$ and €197; p-value $>0.1$ respectively for maternal and paternal education) and for female students (€288; p-value $<0.1$ and $€ 290$; p-value $<0.05$ respectively). Again, most of this differential (between 51\% and 74\%) can be explained by differences in Leaving Certificate performance. ${ }^{19}$

\section{INSERT TABLE 9}

Table 9 shows the decomposition of the relationship between parental education and long run earnings expectations. ${ }^{20}$ An additional year of parental education increases long run earnings expectations on average by $€ 2241$ ( $\mathrm{p}$-value $<0.01$ ). Again, the magnitude of the estimated total impact is similar for males and females ( $€ 1980$ and $€ 2203$ respectively), with both estimates being highly significant (p-values $<0.01$ ). Much less of the total effect between parental education and earnings expectations can be explained in the long run compared to the short run. In the long run, just over half (51\%; p-value $<0.01$ ) of the total differential can be explained through intermediating variables. Slightly more of the male differential is explained compared to the female differential (57\%; p-value $<0.05$ versus $42 \%$; p-value $<0.01)$. The most important factors in explaining the differential are again Leaving Certificate points $(27 \%$ of the pooled differential; p-value $<0.01)$ and college and subject choice (12\% of the pooled differential; p-value $>0.1$ ), although this contribution is not statistically significant.

As in the short run decomposition, gender and risk preferences significantly contribute to explaining the long run differential (5\%, p-value $<0.05$ and $2 \%$; p-value $<0.05$ respectively). In the long run, the personality trait extraversion is statistically significant in explaining the differential $(2 \%$; p-value $<0.05)$, with this trait being particularly important in the female decomposition ( $3 \%$; p-value < 0.05 compared to $1 \%$; p-value $>0.1$ for males).

\footnotetext{
${ }^{19}$ We also decompose the short run earnings expectations differential using maximum parental education; this decomposition yields quantitatively similar results and is shown in the Appendix 2 (Table A2-6).

${ }^{20}$ Partial derivatives corresponding to Table 9 are shown in Table A2-6 of the Appendix, and total derivatives in Table A2-5.
} 
The partial derivative of extraversion with respect to long run earnings expectations is significant and positive, and high SES students are more likely to classify themselves as being extraverted. None of the other four personality traits make a large contribution in explaining the differential (contributions are all $\leq|1 \%|$ and insignificant), nor does future orientation ( $0 \%$; p-value $>0.1)$, age $(-1 \%$; p-value $>0.1)$, year of study $(1 \%$, p-value $>0.1)$ or grade $(1 \%$, p-value $>0.1$ ). Table 10 shows the decomposition separately for paternal and maternal education, showing very similar results for maternal and paternal education. ${ }^{21}$

\section{INSERT TABLE 10}

\section{Conclusion}

This paper analyses the interaction between socio-economic status and higher education, focusing on the entry mechanism into higher education, the academic performance of students in university, and finally, the expected future returns from attending university. The paper also analyses the various mechanisms through which intergenerational transmissions of grade attainment and expected earnings occur, using detailed decompositions that incorporate personality measures, institutional and subject choice, and prior academic performance.

The current university admissions process ispredictive of academic performance in university, and the relationship is robust to the addition of SES controls. This is an indication that the current admissions system is efficient in allocating places in university based on academic aptitude. A small, but significant and positive, gradient was observed between academic achievement in university and SES - on average, 10 years of additional combined parental education is associated with a one-percentage point higher university grade outcome. The relationship between SES and grade attainment in university is much stronger for males than for females. Additionally, maternal education level is more important than paternal education level in predicting educational attainment in university for male students.

\footnotetext{
${ }^{21}$ The long run decomposition using maximum parental education is shown in Table A2-7 of Appendix 2.
} 
Comparison of this socio-economic gradient to the gradient that exists prior to university entry suggests any observed penalty declines significantly over the course of the student's time at University, particularly for female students. We do not find much evidence that SES differences in personality traits, such as risk preferences or conscientiousness, contribute to explaining socio-economic differentials in grade performance.

Importantly, despite the lack of robust evidence of a persistent socio-economic penalty during university, there is a large, significant and persistent differential in terms of the earnings expectations of different socio-economic cohorts. The difference in long-run expected earnings is €2,241 per year of additional parental education, or approximately two percent of the long-run expected income level. Given an average return of approximately eight percent to higher education (Walker and Zhu, 2003), the expected earnings return from parental education is around 25 percent of the actual individual return from higher education. While some of this differential is mediated by our extensive set of demographic, education and personality controls, nearly half of the total effect persists as a direct or unexplained effect.

This differential might be interpreted as evidence that low SES students are anticipating discrimination upon entry into the labour market, or alternatively are genuinely underestimating their returns. This poses a problem for policy makers trying to equalise education attainment across socio-economic cohorts - students make educational choices partly based upon the expected returns from education, and since low SES students have lower expected returns from higher education, unequal participation of low SES cohorts in higher education may reflect rational behaviour on their part based on their own expectations. A further issue is that lowered earnings expectations might result in lower realised earnings due to self-fulfilling expectations. Since we control for grade attainment in our analysis, our 
findings suggest that even if educational attainment is equalised across socio-economic groups, labour market outcomes may not be equalised.

An important direction for further research is to examine the extent to which expectations are self-fulfilling and the extent to which this can explain intergenerational transmission of income, or whether they are a function of anticipated discrimination in the labour market. The results of this paper rule out many traditional explanations of why lower SES students would expect to earn less but still leaves open the possibility that they are rationally embedding labour market discrimination or other unobserved labour market disadvantages into their expectations. Smith and Naylor (2005) provide evidence that secondary school characteristics may play an important role in college performance, something that could potentially explain some of our parental SES effects. 


\section{References}

Allport, G.W. and Odbert, H.S. (1936). 'Trait names: a psycho-lexical study', Psychological Monographs, vol. 47, No. 211.

Black, S.E. and Devereux, P.J. (2010). 'Recent developments in intergenerational mobility’,UCD Geary Institute Discussion Paper Series.

Blinder, A.S. (1973). 'Wage discrimination: reduced form and structural estimates', Journal of Human Resources, vol. 8(4), pp. 436-455.

Borghans, L., Duckworth, A.L., Heckman, J.J. and terWeel, B. (2008). 'The economics and psychology of personality traits', Journal of Human Resources, vol. 47(4), pp. 9721059.

Bowles, S. and Gintis, H. (2002). 'The inheritance of inequality', Journal of Economic Perspectives, vol. 16(3), pp. 3-30.

Denny, K. (2010). 'What did abolishing university fees in Ireland do?', UCD Geary Institute Discussion Paper Series.

Department of Education and Science. (2009). Retention Rates of Pupils in Second Level Schools: 1991 to 2001 Entry Cohorts, Dublin: Department of Education and Science.

Dohmen, T.J., Falk, A., Huffman, D., Sunde, U., Schupp, J. and Wagner, G.G. (2005). 'Individual risk attitudes: new evidence from a large, representative, experimentallyvalidated survey’, IZA Discussion Paper Series. IZA DP No. 1730.

Dohmen, T.J., Falk, A., Huffman, D. and Sunde, U. (2006). 'The intergenerational transmission of risk and trust attitudes', IZA Discussion Paper Series. IZA DP No. 2380.

Dominitz, J. and Manski, C.F. (1996). 'Eliciting student expectations of the returns to schooling', Journal of Human Resources, vol. 31(1), pp. 1-26.

Ermisch, J. and Del Bono, E. (2010). The Link Between the Education Levels of Parents and the Educational Outcomes of Teenagers, London: The Sutton Trust.

Goldberg, L.R. (1981). 'Language and individual differences: the search for universals in personality lexicons', in (L. Wheeler, ed.), Review of Personality and Social Psychology, vol. 2, pp. 141-166, Beverly Hills, CA: Sage Publications.

Goldsmith, H.H, Losoya, S.H., Bradshaw, D.L. and Compos, J.J. (1994). 'Genetics of personality: a twin study of the five factor model and parental-offspring analyses', in (C. F. Halverson, G.A. Kohnstamm and R.P. Martin, eds.), The Developing Structure of Temperament and Personality from Infancy to Adulthood, Hillsdale, NJ: Erlbaum.

Gormley, I.C. and Murphy, T.B. (2006). 'Analysis of Irish third-level college applications data', Journal of the Royal Statistical Society: Series A (Statistics in Society), vol. 169(2), pp. 361-379.

Gosling, S.D., Rentfrow, P.J. and Swann, W.B. (2003). 'A very brief measure of the big-five personality domains', Journal of Research in Personality, vol. 37, pp. 504-528.

Hertz, T., Jayasundera, T., Piraino, P., Selcuk, S., Smith, N. and Verashchagina, A. (2007). 'The inheritance of educational inequality: international comparisons and fifty-year trends', BE Journal of Economic Analysis \& Policy, vol. 7(2), Article 10.

Higher Education Authority. (2010). Student Statistics. Retrieved from http://www.hea.ie/en/statistics (26/07/2010)

Kelly, E., O’Connell, P.J. and Smyth, E. (2010). 'The economics returns to field of study and competencies among higher education graduates in Ireland', Economics of Education Review, vol. 29(4), pp. 650-657.

Machin, S. and Murphy, R. (2010). The Social Composition and Future Earnings of Postgraduates, London: The Sutton Trust. 
Naylor, R.A., and Smith J.P., "Schooling effects on subsequent university performance: evidence for the UK university population,” vol. 24, 549-562, Economics of Education Review, 2005.

Norman, W.T. (1963). 'Toward an adequate taxonomy of personality attributes: replicated factor structure in peer nomination personality ratings', Journal of Abnormal and Social Psychology, vol. 66(6), pp. 574-583.

Oaxaca, R. (1973). 'Male-female wage differentials in urban labor markets', International Economic Review, vol. 14(3), pp. 693-709.

O’Connell, P.J., Clancy, D. and McCoy, S. (2006). 'Who went to college? Socio-economic inequality in entry to higher education in the Republic of Ireland in 2004', Higher Education Quarterly, vol. 60(4), pp. 312-332.

Sackett, P.R., Kuncel, N.R., Arneson, J.J., Cooper, S.R. and Waters, S.D. (2009). Socioeconomic Status and the Relationship between the SAT® and Freshman GPA: An Analysis of Data from 41 Colleges and Universities, New York: College Board.

Shrout, P.E. and Bolger, N. (2002). 'Mediation in experimental and nonexperimental studies: new procedures and recommendations', Psychological Methods, vol. 7(4), pp. 422-445.

Smith, H.L. and Powell, B. (1990). 'Great expectations: variations in income expectations among college seniors', Sociology of Education, vol. 63(3), pp. 194-207.

Strathman, A., Gleicher, F., Boninger, D.S. and Edwards, C.S. (1994). 'The consideration of future consequences: weighing immediate and distant outcomes of behavior', Journal of Personality and Social Psychology, vol. 66(4), pp. 742-752.

Tupes, E.C. and Christal, R.E. (1961). Recurrent Personality Factors Based on Trait Ratings.Technical Report ASD-TR-61-97,Lackland Air Force Base. Texas: US Air Force.

Walker, I. and Zhu, Y. (2003). 'Education, earnings and productivity: recent UK evidence', Labour Market Trends, March, pp. 145-152.

Walker, I. and Zhu, Y. (2010). 'Differences by degree: evidence of the net financial rates of return to undergraduate study for England and Wales', Economics of Education Review, doi: 10.1016/j.econedurev.2011.01.002

Webbink, D. and Hartog, J. (2004). 'Can students predict starting salaries? Yes!',Economics of Education Review, vol. 23(2), pp. 103-113. 
Figure 1: Participation Rates in Higher Education by Father's Socio-Economic Group

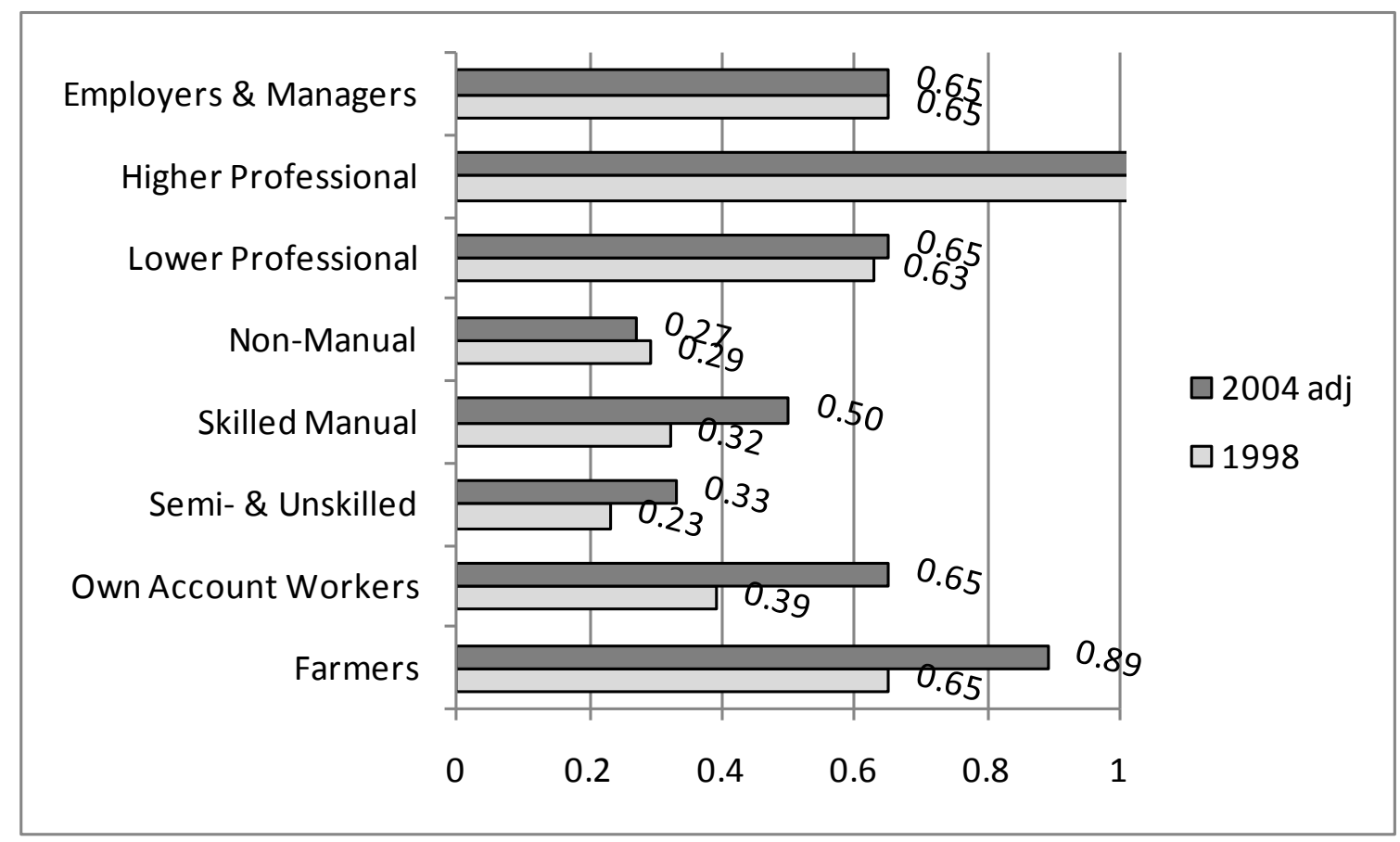

Note: This figure is derived from data in O’Connell et al., 2006. Higher Education participation includes participation in the Universities, the Institutes of Technology and other Colleges of Higher Education.

Figure 2:Distribution of Years of Parental Education

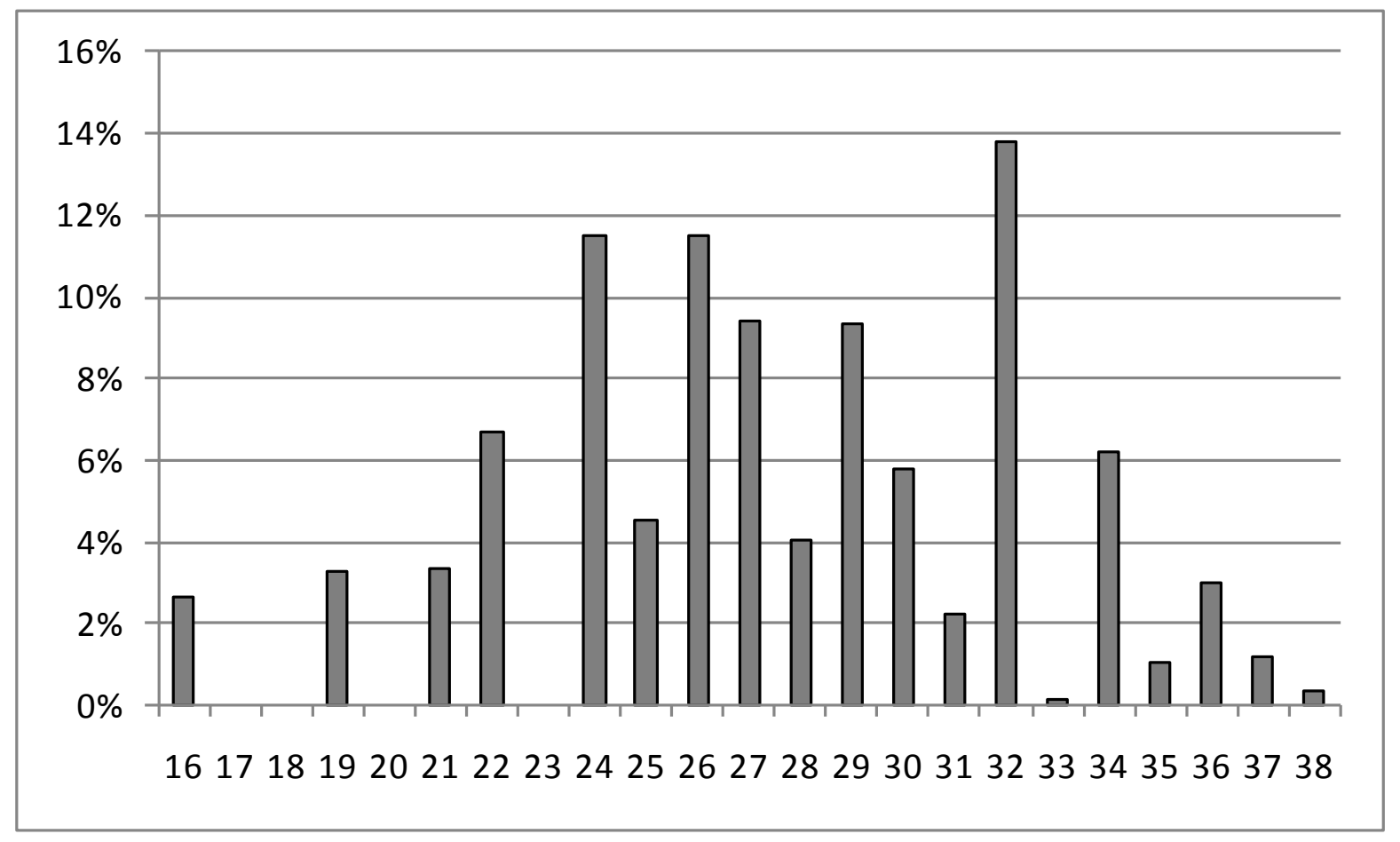


Table 1: Checking Data Robustness: IUS Data versus HEA Data

\begin{tabular}{|c|c|c|c|c|}
\hline Gender & IUS Data Set $2(09 / 10)$ & HEA 2009 & IUS Data Set $1(08 / 09)$ & HEA 2008 \\
\hline Male & $37 \%$ & $43 \%$ & $36 \%$ & $42 \%$ \\
\hline Female & $63 \%$ & $57 \%$ & $64 \%$ & $58 \%$ \\
\hline \multicolumn{5}{|l|}{ University $^{22}$} \\
\hline DCU & $6 \%$ & $9 \%$ & $6 \%$ & $9 \%$ \\
\hline NUIG & $12 \%$ & $16 \%$ & $16 \%$ & $16 \%$ \\
\hline NUIM & $12 \%$ & $8 \%$ & $10 \%$ & $7 \%$ \\
\hline TCD & $19 \%$ & $15 \%$ & $18 \%$ & $15 \%$ \\
\hline UCC & $20 \%$ & $18 \%$ & $17 \%$ & $18 \%$ \\
\hline UCD & $24 \%$ & $23 \%$ & $23 \%$ & $23 \%$ \\
\hline UL & $7 \%$ & $12 \%$ & $10 \%$ & $11 \%$ \\
\hline \multicolumn{5}{|l|}{ Subject } \\
\hline Education & $2 \%$ & $4 \%$ & $3 \%$ & $5 \%$ \\
\hline Humanities \& Arts & $23 \%$ & $25 \%$ & $24 \%$ & $25 \%$ \\
\hline Social Science & $11 \%$ & $7 \%$ & $10 \%$ & $6 \%$ \\
\hline Business & $11 \%$ & $13 \%$ & $12 \%$ & $13 \%$ \\
\hline Law & $4 \%$ & $6 \%$ & $5 \%$ & $7 \%$ \\
\hline Science & $16 \%$ & $12 \%$ & $15 \%$ & $11 \%$ \\
\hline Maths & $3 \%$ & $1 \%$ & $2 \%$ & $1 \%$ \\
\hline Computing & $3 \%$ & $3 \%$ & $3 \%$ & $3 \%$ \\
\hline Engineering & $7 \%$ & $8 \%$ & $8 \%$ & $8 \%$ \\
\hline Agriculture & $2 \%$ & $2 \%$ & $2 \%$ & $2 \%$ \\
\hline Health & $15 \%$ & $18 \%$ & $12 \%$ & $18 \%$ \\
\hline Sport & $0 \%$ & $0 \%$ & $1 \%$ & $0 \%$ \\
\hline Other & $3 \%$ & $2 \%$ & $4 \%$ & $2 \%$ \\
\hline
\end{tabular}

${ }^{22}$ Dublin City University (DCU), National University of Ireland Galway (NUIG), National University of Ireland Maynooth (NUIM), Trinity College Dublin (TCD), University College Cork (UCC), University College Dublin (UCD) and the University of Limerick (UL). 
Table 2:Descriptive Statistics

\begin{tabular}{|c|c|c|c|c|c|c|}
\hline & \multicolumn{3}{|c|}{ Restricted Sample } & \multicolumn{3}{|c|}{ Estimating Sample } \\
\hline Grade Analysis (IUS2) & Obs & Mean & $\sigma$ & Obs & Mean & $\sigma$ \\
\hline Father's Years Education & 2448 & 13.60 & 3.01 & 1866 & 13.62 & 2.98 \\
\hline Mother's Years Education & 2501 & 13.93 & 2.43 & 1866 & 13.96 & 2.41 \\
\hline Combined Parental Education & 2397 & 27.50 & 4.67 & 1866 & 27.59 & 4.64 \\
\hline Maximum Parental Education & 2552 & 14.73 & 2.49 & 1866 & 14.78 & 2.46 \\
\hline Gender & 2669 & 0.62 & 0.49 & 1866 & 0.62 & 0.48 \\
\hline Age & 2669 & 20.39 & 2.12 & 1866 & 20.44 & 2.08 \\
\hline Year & 2669 & 2.33 & 1.05 & 1866 & 2.40 & 1.05 \\
\hline College & 2669 & - & - & 1866 & - & - \\
\hline Subject & 2666 & - & - & 1866 & - & - \\
\hline University Grade (\%) & 2082 & 64.65 & 10.52 & 1866 & 64.76 & 10.55 \\
\hline Leaving Certificate Points & 2610 & 463.67 & 78.94 & 1866 & 468.49 & 76.93 \\
\hline Risk Willingness & 2379 & 6.04 & 1.86 & 1866 & 6.01 & 1.86 \\
\hline Consideration of Future Consequences & 2323 & 13.61 & 3.45 & 1866 & 13.72 & 3.46 \\
\hline Earnings Analysis (IUS1) & Obs & Mean & $\sigma$ & Obs & Mean & $\sigma$ \\
\hline Father's Years Education & 2261 & 13.48 & 2.99 & 1873 & 13.52 & 2.98 \\
\hline Mother's Years Education & 2300 & 13.80 & 2.48 & 1873 & 13.79 & 2.46 \\
\hline Combined Parental Education & 2219 & 27.25 & 4.73 & 1873 & 27.31 & 4.70 \\
\hline Maximum Parental Education & 2342 & 14.60 & 2.53 & 1873 & 14.65 & 2.50 \\
\hline Gender & 2472 & 0.64 & 0.48 & 1873 & 0.65 & 0.48 \\
\hline Age & 2472 & 20.29 & 2.00 & 1873 & 20.30 & 1.96 \\
\hline Year & 2472 & 2.26 & 1.09 & 1873 & 2.30 & 1.09 \\
\hline College & 2472 & - & - & 1873 & - & - \\
\hline Subject & 2467 & - & - & 1873 & - & - \\
\hline University Grade (Converted to approx \%) & 2210 & 63.43 & 10.52 & 1873 & 63.65 & 10.53 \\
\hline Leaving Certificate Points & 2394 & 464.92 & 73.46 & 1873 & 467.62 & 73.55 \\
\hline Risk Willingness & 2229 & 6.47 & 1.73 & 1873 & 6.47 & 1.71 \\
\hline Extraversion & 2228 & 9.22 & 2.71 & 1873 & 9.28 & 2.70 \\
\hline Agreeableness & 2228 & 6.23 & 2.22 & 1873 & 6.21 & 2.22 \\
\hline Conscientiousness & 2228 & 10.21 & 2.61 & 1873 & 10.23 & 2.61 \\
\hline Neuroticism & 2228 & 6.67 & 2.79 & 1873 & 6.68 & 2.81 \\
\hline Openness & 2229 & 10.74 & 2.07 & 1873 & 10.77 & 2.06 \\
\hline Consideration of Future Consequences & 2212 & 13.43 & 3.63 & 1873 & 13.53 & 3.66 \\
\hline First Salary Expectation & 2063 & 31,869 & 13,990 & 1873 & 32,104 & 14,085 \\
\hline Maximum Salary Expectation & 2062 & 102,958 & 51,042 & 1871 & 103,838 & 50,796 \\
\hline
\end{tabular}


Table 3: Efficiency of Admissions System

\begin{tabular}{|c|c|c|}
\hline VARIABLES & $\begin{array}{c}\text { (1) } \\
\text { University Grade }\end{array}$ & $\begin{array}{c}\text { (2) } \\
\text { University Grade }\end{array}$ \\
\hline Leaving Certificate & $\begin{array}{r}0.031^{* * *} \\
(0.003)\end{array}$ & $\begin{array}{r}0.035^{* * *} \\
(0.003)\end{array}$ \\
\hline Parental Education & & $\begin{array}{r}-0.049 \\
(0.053)\end{array}$ \\
\hline Female & $\begin{array}{r}0.244 \\
(0.469)\end{array}$ & $\begin{array}{r}0.040 \\
(0.491)\end{array}$ \\
\hline Age & $\begin{array}{r}-7.025^{* * *} \\
(1.296)\end{array}$ & $\begin{array}{r}-7.249 * * * \\
(1.366)\end{array}$ \\
\hline Age $^{\wedge} 2$ & $\begin{array}{r}0.161 * * * \\
(0.029)\end{array}$ & $\begin{array}{r}0.168^{* * *} \\
(0.031)\end{array}$ \\
\hline Constant & $\begin{array}{r}125.704^{* * *} \\
(14.212)\end{array}$ & $\begin{array}{r}127.276^{* * *} \\
(15.004)\end{array}$ \\
\hline $\begin{array}{l}\text { Observations } \\
\text { R-squared }\end{array}$ & $\begin{array}{r}2034 \\
0.058\end{array}$ & $\begin{array}{r}1867 \\
0.064\end{array}$ \\
\hline
\end{tabular}

Note: This table reports the results from two linear models of grade attainment. The first column estimates the relationship between university grade attainment and secondary school performance (as measured by Leaving Certificate points), and also controls for a set of demographic controls. The second column estimates the same model, but includes sum years of parental education to control for socio-economic status. University grade is measured on a scale of between $0-100$, therefore the coefficient on Leaving Certificate implies that 100 additional Leaving Certificate points is associated with a $3 \%$ higher grade in university. 
Table 4: Grade Decomposition using Summed Parental Education

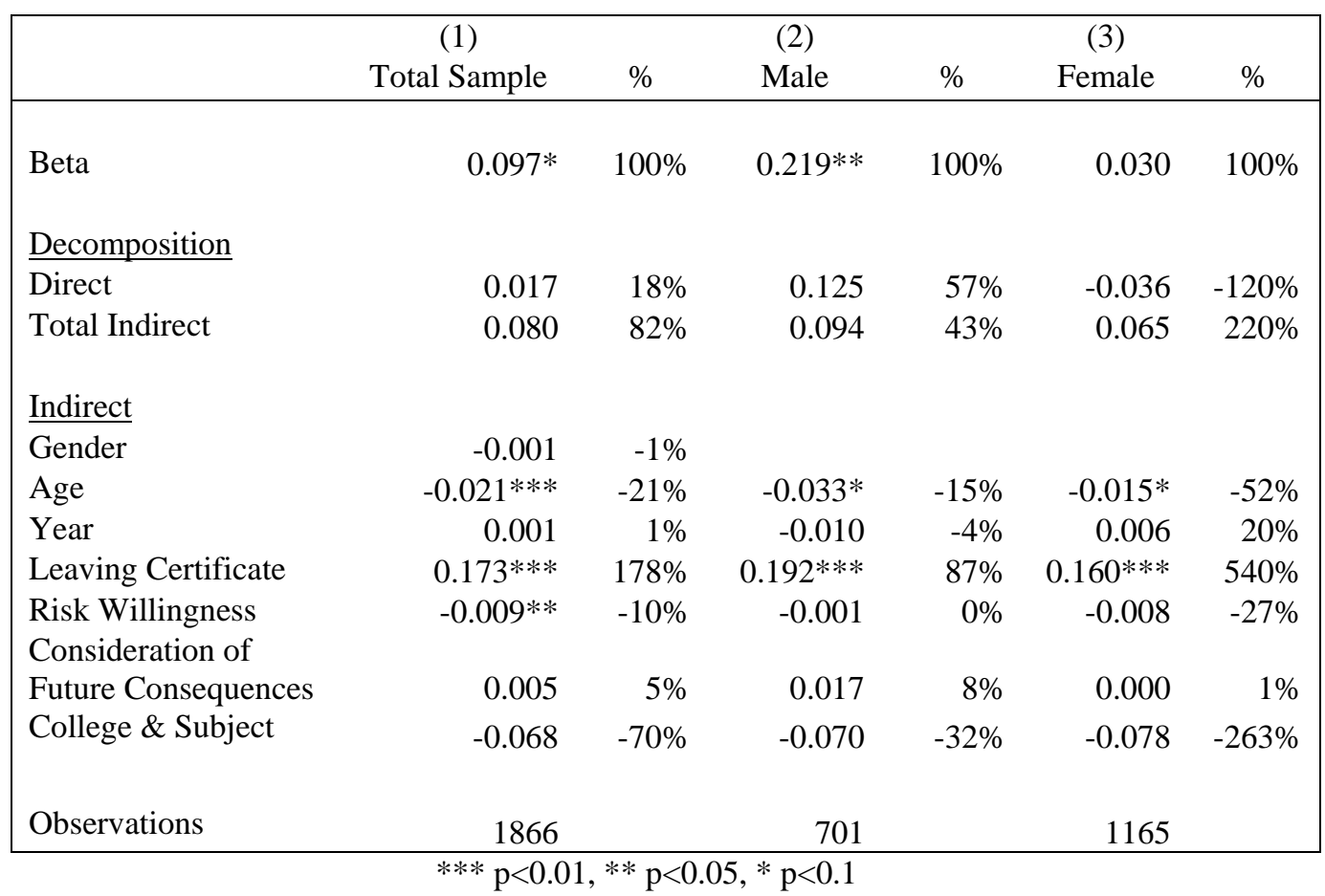

Note: This table shows the results from a number of grade decompositions. The first column estimates the decomposition for the entire sample. The second column estimates the same model for male students only and the final column estimates the model for female students only. Standard errors were computed using bootstrapped estimation with 2000 replications. In all decompositions, the first stage total effect of SES on gender is estimated using a linear probability model. As college and subject are categorical, estimation of individual college or subject contributions are not estimated. The combined effects of college and subject choice are estimated as the residual of the total effect less the direct effect and the sum of the other indirect effects. 
Table 5: Grade Decomposition using Father and Mother’s Education Separately

\begin{tabular}{|c|c|c|c|c|c|c|c|c|c|c|c|c|}
\hline & $\begin{array}{c}(1) \\
\text { All Sample } \\
\text { Father }\end{array}$ & $\%$ & $\begin{array}{c}\text { (2) } \\
\text { All Sample } \\
\text { Mother }\end{array}$ & $\%$ & $\begin{array}{c}\text { (3) } \\
\text { Male Father }\end{array}$ & $\%$ & $\begin{array}{c}\text { (4) } \\
\text { Female } \\
\text { Father }\end{array}$ & $\%$ & $\begin{array}{c}(5) \\
\text { Male } \\
\text { Mother }\end{array}$ & $\%$ & $\begin{array}{c}\text { (6) } \\
\text { Female } \\
\text { Mother }\end{array}$ & $\%$ \\
\hline Beta & 0.129 & $100 \%$ & 0.158 & $100 \%$ & $0.247 *$ & $100 \%$ & 0.064 & $100 \%$ & $0.389 * *$ & $100 \%$ & 0.035 & $100 \%$ \\
\hline \multicolumn{13}{|l|}{$\underline{\text { Decomposition }}$} \\
\hline Direct & 0.033 & $26 \%$ & 0.026 & $16 \%$ & 0.121 & $49 \%$ & -0.013 & $-20 \%$ & 0.215 & $55 \%$ & -0.060 & $-172 \%$ \\
\hline Indirect & 0.096 & $74 \%$ & 0.132 & $84 \%$ & 0.126 & $51 \%$ & 0.077 & $120 \%$ & 0.174 & $45 \%$ & 0.095 & $272 \%$ \\
\hline \multicolumn{13}{|l|}{ Indirect } \\
\hline$\overline{\text { Gender }}$ & -0.002 & $-1 \%$ & -0.002 & $-1 \%$ & & & & & & & & \\
\hline Age & $-0.027 * *$ & $-21 \%$ & $-0.029 * *$ & $-19 \%$ & $-0.048 *$ & $-19 \%$ & $-0.019 *$ & $-29 \%$ & -0.046 & $-12 \%$ & -0.022 & $-63 \%$ \\
\hline Year & 0.005 & $4 \%$ & -0.004 & $-3 \%$ & -0.004 & $-1 \%$ & 0.009 & $13 \%$ & -0.030 & $-8 \%$ & 0.008 & $23 \%$ \\
\hline Leaving Certificate & $0.231 * * *$ & $179 \%$ & $0.269 * * *$ & $170 \%$ & $0.263^{* * *}$ & $106 \%$ & $0.216^{* * *}$ & $336 \%$ & $0.351 * * *$ & $90 \%$ & $0.222 * * *$ & $639 \%$ \\
\hline Risk Willingness & $-0.013^{*}$ & $-10 \%$ & $-0.018 *$ & $-11 \%$ & -0.004 & $-2 \%$ & -0.009 & $-15 \%$ & -0.001 & $0 \%$ & -0.017 & $-49 \%$ \\
\hline $\begin{array}{l}\text { Consideration of } \\
\text { Future }\end{array}$ & & & & & & & & & & & & \\
\hline Consequences & 0.007 & $5 \%$ & -0.086 & $-55 \%$ & 0.024 & $10 \%$ & -0.001 & $-1 \%$ & 0.009 & $2 \%$ & 0.001 & $4 \%$ \\
\hline College \& Subject & -0.106 & $-82 \%$ & 0.004 & $2 \%$ & -0.106 & $-43 \%$ & -0.118 & $-184 \%$ & -0.109 & $-28 \%$ & -0.098 & $-282 \%$ \\
\hline Observations & 1904 & & 1941 & & 721 & & 1183 & & 732 & & 1209 & \\
\hline
\end{tabular}

Note: This table shows the results from a number of grade decompositions. The first column uses father's education level as the explanatory variable. The second column estimates the same model but uses mother's education level as the explanatory variable. Columns 3-6 estimate these two model specifications separately for male and female respondents. Standard errors were computed using bootstrapped estimation with 2000 replications. 
Table 6: Grade Gradient: Comparing School \& University

\begin{tabular}{|c|c|c|c|c|c|c|}
\hline VARIABLES & $\begin{array}{c}(1) \\
\text { Leaving } \\
\text { Certificate- } \\
\text { All Sample } \\
\end{array}$ & $\begin{array}{c}\text { (2) } \\
\text { University } \\
\text { Grade - All } \\
\text { Sample } \\
\end{array}$ & $\begin{array}{c}(3) \\
\text { Leaving } \\
\text { Certificate - } \\
\text { Males } \\
\end{array}$ & $\begin{array}{c}(4) \\
\text { University } \\
\text { Grade - } \\
\text { Males } \\
\end{array}$ & $\begin{array}{c}(5) \\
\text { Leaving } \\
\text { Certificate - } \\
\text { Females } \\
\end{array}$ & $\begin{array}{c}(6) \\
\text { University } \\
\text { Grade - } \\
\text { Females } \\
\end{array}$ \\
\hline Parental Education & $\begin{array}{r}0.060 * * * \\
(0.000)\end{array}$ & $\begin{array}{c}0.009^{*} \\
(0.059)\end{array}$ & $\begin{array}{r}0.059^{* * *} \\
(0.000)\end{array}$ & $\begin{array}{r}0.020^{* *} \\
(0.016)\end{array}$ & $\begin{array}{r}0.060^{* * *} \\
(0.000)\end{array}$ & $\begin{array}{r}0.003 \\
(0.580)\end{array}$ \\
\hline Female & $\begin{array}{r}0.098^{* *} \\
(0.014)\end{array}$ & $\begin{array}{r}0.034 \\
(0.473)\end{array}$ & & & & \\
\hline Age & $\begin{array}{r}0.748 * * * \\
(0.000)\end{array}$ & $\begin{array}{r}-0.489 * * * \\
(0.000)\end{array}$ & $\begin{array}{r}0.736^{* * * *} \\
(0.000)\end{array}$ & $\begin{array}{r}-0.705^{* * *} \\
(0.001)\end{array}$ & $\begin{array}{r}0.742^{* * *} \\
(0.000)\end{array}$ & $\begin{array}{r}-0.362^{* *} \\
(0.028)\end{array}$ \\
\hline Age $^{\wedge} 2$ & $\begin{array}{r}-0.019 * * * \\
(0.000)\end{array}$ & $\begin{array}{r}0.011^{* * *} \\
(0.000)\end{array}$ & $\begin{array}{r}-0.019 * * * \\
(0.000)\end{array}$ & $\begin{array}{r}0.016^{* * *} \\
(0.001)\end{array}$ & $\begin{array}{r}-0.018 * * * \\
(0.000)\end{array}$ & $\begin{array}{r}0.008^{* *} \\
(0.032)\end{array}$ \\
\hline Observations & 2342 & 1914 & 883 & 713 & 1459 & 1201 \\
\hline
\end{tabular}

Note: This table reports the results from a number of linear models of grade attainment both prior to university and in university. Reported coefficients are standardized regression coefficients with the outcome variables in measured in standard deviations. 
Table 7: Short-Run Earnings Decomposition using Summed Parental Education

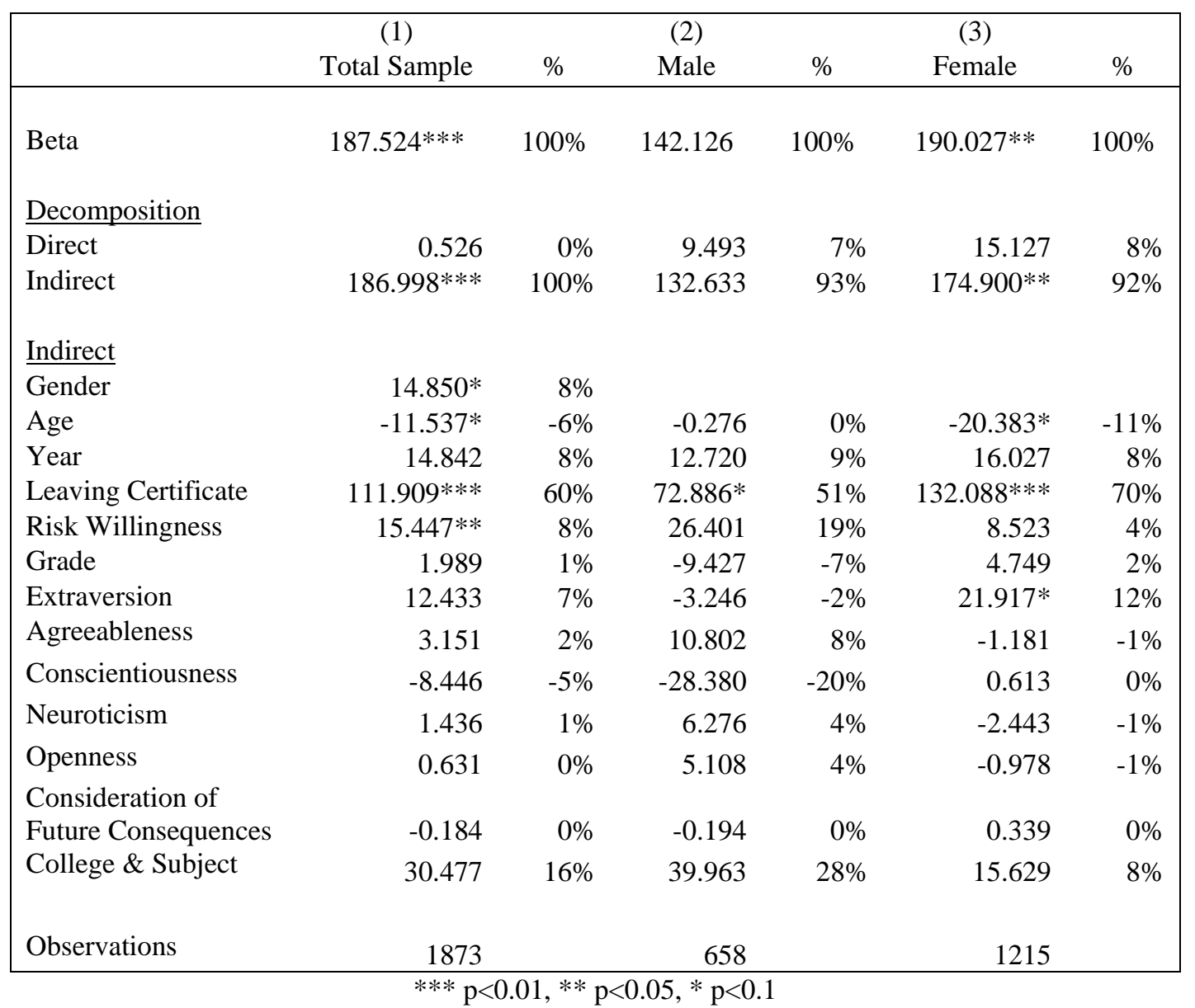

Note: This table shows the results from a number of decompositions of short run earnings expectations. The first column estimates the decomposition for the entire sample. The second column estimates the same model for male students only and the final column estimates the model for female students only. Standard errors were computed using bootstrapped estimation with 2000 replications. 
Table 8: Short-Run Earnings Decomposition using Father and Mother’s Education Separately

\begin{tabular}{|c|c|c|c|c|c|c|c|c|c|c|c|c|}
\hline & $\begin{array}{c}\text { (1) } \\
\text { All Sample } \\
\text { Father }\end{array}$ & $\%$ & $\begin{array}{c}(2) \\
\text { All Sample } \\
\text { Mother }\end{array}$ & $\%$ & $\begin{array}{c}\text { (3) } \\
\text { Male } \\
\text { Father }\end{array}$ & $\%$ & $\begin{array}{c}(4) \\
\text { Female } \\
\text { Father }\end{array}$ & $\%$ & $\begin{array}{c}(5) \\
\text { Male } \\
\text { Mother }\end{array}$ & $\%$ & $\begin{array}{c}(6) \\
\text { Female } \\
\text { Mother }\end{array}$ & $\%$ \\
\hline Beta & $290.783 * * *$ & $100 \%$ & $262.099 * *$ & $100 \%$ & 196.768 & $100 \%$ & $290.296 * *$ & $\begin{array}{r}100 \\
\%\end{array}$ & 206.484 & $100 \%$ & 288.109* & $100 \%$ \\
\hline \multicolumn{13}{|l|}{$\underline{\text { Decomposition }}$} \\
\hline Direct & 34.538 & $12 \%$ & -30.113 & $-11 \%$ & -4.205 & $-2 \%$ & 65.371 & $23 \%$ & 17.364 & $8 \%$ & -11.517 & $-4 \%$ \\
\hline Indirect & $256.245^{* *}$ & $88 \%$ & $292.212^{* *}$ & $111 \%$ & 200.973 & $102 \%$ & $224.926^{*}$ & $77 \%$ & 189.119 & $92 \%$ & 299.625* & $104 \%$ \\
\hline \multicolumn{13}{|l|}{$\underline{\text { Indirect }}$} \\
\hline Gender & $34.772 * *$ & $12 \%$ & 2.920 & $1 \%$ & & & & & & & & \\
\hline Age & -10.817 & $-4 \%$ & $-24.753 *$ & $-9 \%$ & 3.803 & $2 \%$ & $-21.971 *$ & $-8 \%$ & -4.553 & $-2 \%$ & $-38.349 *$ & $-13 \%$ \\
\hline Year & 2.241 & $1 \%$ & $47.085^{* *}$ & $18 \%$ & 9.531 & $5 \%$ & -1.623 & $-1 \%$ & 27.404 & $13 \%$ & $58.121^{* *}$ & $20 \%$ \\
\hline Leaving Certificate & $151.363 * * *$ & $52 \%$ & $180.971^{* * *}$ & $69 \%$ & 99.876* & $51 \%$ & $180.028 * * *$ & $62 \%$ & 108.159* & $52 \%$ & $212.581 * * *$ & $74 \%$ \\
\hline Risk Willingness & $20.857^{*}$ & $7 \%$ & $23.825^{*}$ & $9 \%$ & 37.777 & $19 \%$ & 9.762 & $3 \%$ & 30.516 & $15 \%$ & 18.733 & $7 \%$ \\
\hline Grade & 2.303 & $1 \%$ & 3.232 & $1 \%$ & -15.094 & $-8 \%$ & 9.053 & $3 \%$ & -19.280 & $-9 \%$ & 3.745 & $1 \%$ \\
\hline Extraversion & $19.526^{*}$ & $7 \%$ & 20.065 & $8 \%$ & -6.566 & $-3 \%$ & $32.379 *$ & $11 \%$ & 1.126 & $1 \%$ & $34.676^{*}$ & $12 \%$ \\
\hline Agreeableness & 4.284 & $1 \%$ & 4.260 & $2 \%$ & 7.668 & $4 \%$ & -0.631 & $0 \%$ & 31.464 & $15 \%$ & -1.850 & $-1 \%$ \\
\hline Conscientiousness & -8.467 & $-3 \%$ & -19.016 & $-7 \%$ & -23.378 & $-12 \%$ & 0.697 & $0 \%$ & $-68.036 *$ & $-33 \%$ & 0.783 & $0 \%$ \\
\hline Neuroticism & 2.126 & $1 \%$ & 2.178 & $1 \%$ & 12.040 & $6 \%$ & -1.942 & $-1 \%$ & 0.313 & $0 \%$ & -3.430 & $-1 \%$ \\
\hline Openness & 1.035 & $0 \%$ & -0.312 & $0 \%$ & 8.390 & $4 \%$ & -1.528 & $-1 \%$ & 2.764 & $1 \%$ & -3.161 & $-1 \%$ \\
\hline $\begin{array}{l}\text { Consideration of } \\
\text { Future Consequences }\end{array}$ & 0.982 & $0 \%$ & -1.888 & $-1 \%$ & 0.197 & $0 \%$ & 1.724 & $1 \%$ & 0.007 & $0 \%$ & -1.708 & $-1 \%$ \\
\hline College \& Subject & 36.040 & $12 \%$ & 53.646 & $20 \%$ & 66.730 & $34 \%$ & 18.976 & $7 \%$ & 79.236 & $38 \%$ & 19.485 & $7 \%$ \\
\hline Observations & 1901 & & 1944 & & 675 & & 1226 & & 685 & & 1259 & \\
\hline
\end{tabular}

Note: This table shows the results from a number of decompositions of short run earnings expectations. The first column uses father's education level as the explanatory variable. The second column estimates the same model but uses mother's education level as the explanatory variable. Columns 3-6 estimate these two model specifications separately for male and female respondents. Standard errors were computed using bootstrapped estimation with 2000 replications. 
Table 9: Long-Run Earnings Decomposition using Summed Parental Education

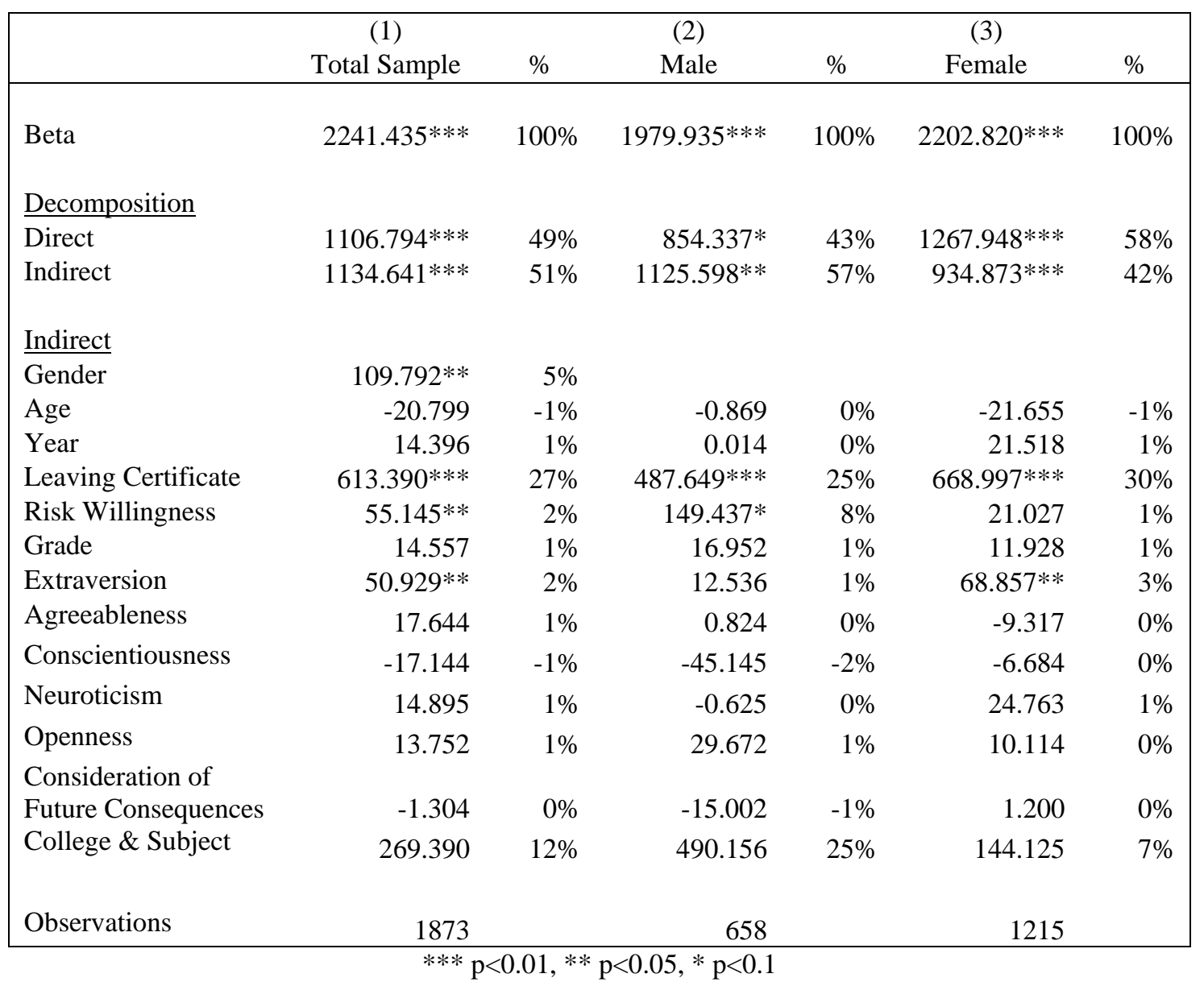

Note: This table shows the results from a number of decompositions of long run earnings expectations. The first column estimates the decomposition for the entire sample. The second column estimates the same model for male students only and the final column estimates the model for female students only. Standard errors were computed using bootstrapped estimation with 2000 replications. 
Table 10: Long-Run Earnings Decomposition using Father and Mother’s Education Separately

\begin{tabular}{|c|c|c|c|c|c|c|c|c|c|c|c|c|}
\hline & $\begin{array}{c}(1) \\
\text { All Sample } \\
\text { Father }\end{array}$ & $\%$ & $\begin{array}{c}(2) \\
\text { All Sample } \\
\text { Mother }\end{array}$ & $\%$ & $\begin{array}{c}\text { (3) } \\
\text { Male Father }\end{array}$ & $\%$ & $\begin{array}{c}\text { (4) } \\
\text { Female Father }\end{array}$ & $\%$ & $\begin{array}{c}\text { (5) } \\
\text { Male Mother }\end{array}$ & $\%$ & $\begin{array}{c}\text { (6) } \\
\text { Female } \\
\text { Mother }\end{array}$ & $\%$ \\
\hline Beta & $3074.174 * * *$ & $100 \%$ & $3510.306 * * *$ & $100 \%$ & $2685.064 * * *$ & $100 \%$ & $2863.572 * * *$ & $100 \%$ & $3147.781 * * *$ & $100 \%$ & $3674.172 * * *$ & $100 \%$ \\
\hline \multicolumn{13}{|l|}{ Decomposition } \\
\hline Direct & 1320.896*** & $43 \%$ & $1805.640 * * *$ & $51 \%$ & 865.300 & $32 \%$ & 1552.299*** & $54 \%$ & 1629.526* & $52 \%$ & 2014.194*** & $55 \%$ \\
\hline Indirect & 1753.278*** & $57 \%$ & $1704.666^{* * *}$ & $49 \%$ & $1819.764^{* *}$ & $68 \%$ & $1311.274^{* * *}$ & $46 \%$ & 1518.255* & $48 \%$ & $1659.978 * * *$ & $45 \%$ \\
\hline \multicolumn{13}{|l|}{$\underline{\text { Indirect }}$} \\
\hline Gender & $256.292 * * *$ & $8 \%$ & 20.381 & $1 \%$ & & & & & & & & \\
\hline Age & -20.146 & $-1 \%$ & -45.766 & $-1 \%$ & 12.331 & $0 \%$ & -23.869 & $-1 \%$ & -18.839 & $-1 \%$ & -33.194 & $-1 \%$ \\
\hline Year & 2.072 & $0 \%$ & 53.389 & $2 \%$ & 3.271 & $0 \%$ & -3.413 & $0 \%$ & 19.222 & $1 \%$ & 77.278 & $2 \%$ \\
\hline Leaving Certificate & $881.885 * * *$ & $29 \%$ & $1023.351 * * *$ & $29 \%$ & $672.243 * * *$ & $25 \%$ & $985.175 * * *$ & $34 \%$ & $852.221 * * *$ & $27 \%$ & $1073.447 * * *$ & $29 \%$ \\
\hline Risk Willingness & 82.906* & $3 \%$ & 80.897 & $2 \%$ & 217.254* & $8 \%$ & 27.844 & $1 \%$ & 167.872 & $5 \%$ & 45.554 & $1 \%$ \\
\hline Grade & 20.314 & $1 \%$ & 18.601 & $1 \%$ & 25.083 & $1 \%$ & 20.269 & $1 \%$ & 29.457 & $1 \%$ & 9.377 & $0 \%$ \\
\hline Extraversion & $82.182 * *$ & $3 \%$ & $70.770 *$ & $2 \%$ & 21.452 & $1 \%$ & $108.138 * *$ & $4 \%$ & 23.337 & $1 \%$ & $98.782 *$ & $3 \%$ \\
\hline Agreeableness & 29.709 & $1 \%$ & 27.190 & $1 \%$ & 4.200 & $0 \%$ & -4.885 & $0 \%$ & 35.997 & $1 \%$ & -22.043 & $-1 \%$ \\
\hline Conscientiousness & -14.013 & $0 \%$ & -27.458 & $-1 \%$ & -31.775 & $-1 \%$ & -3.868 & $0 \%$ & -110.353 & $-4 \%$ & -0.021 & $0 \%$ \\
\hline Neuroticism & 22.498 & $1 \%$ & 23.649 & $1 \%$ & -4.594 & $0 \%$ & 24.235 & $1 \%$ & -0.078 & $0 \%$ & 63.980 & $2 \%$ \\
\hline Openness & 21.706 & $1 \%$ & 15.726 & $0 \%$ & 52.304 & $2 \%$ & 16.537 & $1 \%$ & 18.669 & $1 \%$ & 12.451 & $0 \%$ \\
\hline $\begin{array}{l}\text { Consideration of } \\
\text { Future Consequences }\end{array}$ & 9.057 & $0 \%$ & -27.595 & $-1 \%$ & 12.459 & $0 \%$ & 5.111 & $0 \%$ & -85.067 & $-3 \%$ & -8.597 & $0 \%$ \\
\hline College \& Subject & 378.816 & $12 \%$ & 471.531 & $13 \%$ & 835.535 & $31 \%$ & 159.999 & $6 \%$ & 585.814 & $19 \%$ & 342.964 & $9 \%$ \\
\hline Observations & 1901 & & 1943 & & 675 & & 1226 & & 685 & & 1258 & \\
\hline
\end{tabular}

Note: This table shows the results from a number of decompositions of long run earnings expectations. The first column uses father's education level as the explanatory variable. The second column estimates the same model but uses mother's education level as the explanatory variable. Columns 3-6 estimate these two model specifications separately for male and female respondents. Standard errors were computed using bootstrapped estimation with 2000 replications. 


\section{Appendix 1: Question Wording}

\section{Consideration of Future Consequences Question Wording}

The response scale for this question was:

1 Extremely uncharacteristic

2 Somewhat uncharacteristic

3 Uncertain

4 Somewhat characteristic

5 Extremely characteristic

"For each of the statements below, please indicate whether or not the statement is characteristic of you
a) I consider how things might be in the future, and try to influence those things with my day to day behaviour
b) Often I engage in a particular behaviour in order to achieve outcomes that may not result for many years
c) I only act to satisfy immediate concerns, figuring the future will take care of itself
d) My behaviour is only influenced by the immediate i.e. a matter of days or weeks"

\section{TIPI Question Wording}

The response scale for this question was:

1 Disagree Strongly

2 Disagree Moderately

3 Disagree a little

4 Neither agree nor disagree

5 Agree a little

6 Agree Moderately

7 Agree Strongly

"Here are a number of personality traits that may or may not apply to you. Please indicate next to each statement the extent to which you agree or disagree with that statement. You should rate the extent to which the pair of traits applies to you, even if one characteristic applies more strongly than the other. I see myself as:"
a) Extraverted, enthusiastic
b) Reserved, quiet
Extraversion
c) Critical, quarrelsome
d) Sympathetic, warm

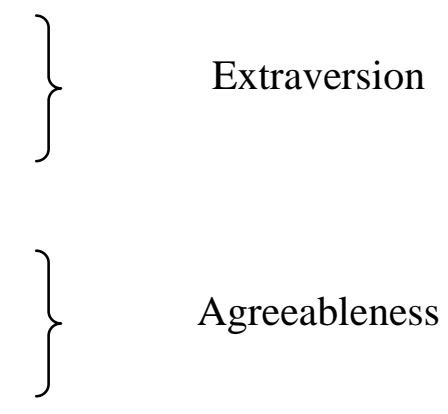


e) Dependable, self-disciplined

f) Disorganized, careless

g) Anxious, easily upset

h) Calm, emotionally stable

i) Open to new experiences, complex

j) Conventional, uncreative

\section{Conscientiousness}

Neuroticism

Openness 
Appendix 2: Partial and Total Derivatives

Table A2-1: Partial Derivatives (Table 4)

\begin{tabular}{|c|c|c|c|}
\hline VARIABLES & $\begin{array}{c}(1) \\
\text { All Sample } \\
\end{array}$ & $\begin{array}{l}\text { (2) } \\
\text { Male } \\
\end{array}$ & $\begin{array}{c}(3) \\
\text { Female } \\
\end{array}$ \\
\hline Parental Education & $\begin{array}{c}0.017 \\
(0.746)\end{array}$ & $\begin{array}{c}0.125 \\
(0.169)\end{array}$ & $\begin{array}{l}-0.036 \\
(0.583)\end{array}$ \\
\hline Gender & $\begin{array}{c}0.170 \\
(0.732)\end{array}$ & & \\
\hline Age & $\begin{array}{c}0.505 * * * \\
(0.000)\end{array}$ & $\begin{array}{c}0.658 * * * \\
(0.002)\end{array}$ & $\begin{array}{l}0.407 * * \\
(0.014)\end{array}$ \\
\hline Year & $\begin{array}{c}-0.852 * * * \\
(0.001)\end{array}$ & $\begin{array}{c}-0.892 * * \\
(0.031)\end{array}$ & $\begin{array}{c}-0.790^{* * *} \\
(0.011)\end{array}$ \\
\hline Humanities \& Arts & $\begin{array}{l}-1.994 \\
(0.240)\end{array}$ & $\begin{array}{l}-1.432 \\
(0.627)\end{array}$ & $\begin{array}{l}-3.089 \\
(0.139)\end{array}$ \\
\hline Social Science & $\begin{array}{l}-3.438^{*} \\
(0.053)\end{array}$ & $\begin{array}{l}-3.751 \\
(0.236)\end{array}$ & $\begin{array}{l}-3.936^{*} \\
(0.069)\end{array}$ \\
\hline Business & $\begin{array}{l}-2.425 \\
(0.169)\end{array}$ & $\begin{array}{l}-3.363 \\
(0.265)\end{array}$ & $\begin{array}{l}-2.609 \\
(0.234)\end{array}$ \\
\hline Law & $\begin{array}{c}-5.831^{* * * *} \\
(0.003)\end{array}$ & $\begin{array}{l}-4.188 \\
(0.226)\end{array}$ & $\begin{array}{c}-7.044^{* * *} \\
(0.003)\end{array}$ \\
\hline Science & $\begin{array}{l}-2.375 \\
(0.166)\end{array}$ & $\begin{array}{l}-1.967 \\
(0.507)\end{array}$ & $\begin{array}{l}-3.394 \\
(0.109)\end{array}$ \\
\hline Maths & $\begin{array}{l}-3.607^{*} \\
(0.093)\end{array}$ & $\begin{array}{l}-3.548 \\
(0.299)\end{array}$ & $\begin{array}{l}-4.659 \\
(0.107)\end{array}$ \\
\hline Computer Science & $\begin{array}{l}-3.733^{*} \\
(0.089)\end{array}$ & $\begin{array}{l}-5.839 * \\
(0.078)\end{array}$ & $\begin{array}{l}-0.025 \\
(0.994)\end{array}$ \\
\hline Eng/Manu/Const. & $\begin{array}{l}-3.292^{*} \\
(0.071)\end{array}$ & $\begin{array}{l}-4.073 \\
(0.172)\end{array}$ & $\begin{array}{l}-2.680 \\
(0.274)\end{array}$ \\
\hline Agri/Veterinary & $\begin{array}{l}-2.775 \\
(0.243)\end{array}$ & $\begin{array}{l}-6.826^{*} \\
(0.080)\end{array}$ & $\begin{array}{l}-0.122 \\
(0.968)\end{array}$ \\
\hline Health/Welfare & $\begin{array}{l}-2.054 \\
(0.244)\end{array}$ & $\begin{array}{l}-3.482 \\
(0.286)\end{array}$ & $\begin{array}{l}-2.145 \\
(0.315)\end{array}$ \\
\hline Sport/Catering/Serv. & $\begin{array}{l}-4.101 \\
(0.224)\end{array}$ & $\begin{array}{l}-3.459 \\
(0.519)\end{array}$ & $\begin{array}{l}-5.076 \\
(0.247)\end{array}$ \\
\hline Other & $\begin{array}{l}-3.302 \\
(0.110)\end{array}$ & $\begin{array}{l}-6.757^{*} \\
(0.057)\end{array}$ & $\begin{array}{l}-1.871 \\
(0.465)\end{array}$ \\
\hline UCD & $\begin{array}{c}4.019 * * * \\
(0.000)\end{array}$ & $\begin{array}{c}3.370 * * * \\
(0.005)\end{array}$ & $\begin{array}{c}4.732 * * * \\
(0.000)\end{array}$ \\
\hline NUIM & $\begin{array}{c}1.164 \\
(0.174)\end{array}$ & $\begin{array}{c}0.315 \\
(0.841)\end{array}$ & $\begin{array}{l}1.864^{*} \\
(0.067)\end{array}$ \\
\hline NUIG & $\begin{array}{l}-0.190 \\
(0.825)\end{array}$ & $\begin{array}{c}0.361 \\
(0.824)\end{array}$ & $\begin{array}{l}-0.195 \\
(0.846)\end{array}$ \\
\hline TCD & $\begin{array}{c}-2.586 * * * \\
(0.001)\end{array}$ & $\begin{array}{l}-2.039 \\
(0.116)\end{array}$ & $\begin{array}{c}-2.745^{* * *} \\
(0.003)\end{array}$ \\
\hline UL & $\begin{array}{c}6.316^{* * * *} \\
(0.000)\end{array}$ & $\begin{array}{c}5.126 * * * \\
(0.002)\end{array}$ & $\begin{array}{c}6.896 * * * \\
(0.000)\end{array}$ \\
\hline DCU & $\begin{array}{c}0.511 \\
(0.653)\end{array}$ & $\begin{array}{c}-0.704 \\
(0.709)\end{array}$ & $\begin{array}{l}1.806 \\
(0.209)\end{array}$ \\
\hline $\begin{array}{l}\text { Leaving Certificate } \\
\text { (cont....) }\end{array}$ & $0.036^{* * *}$ & $0.034 * * *$ & $0.035^{* * *}$ \\
\hline
\end{tabular}


Table A2-1: Partial Derivatives (Table 4) - continued

\begin{tabular}{|c|c|c|c|}
\hline VARIABLES & $\begin{array}{l}(1) \\
\text { All Sample } \\
\end{array}$ & $\begin{array}{l}(2) \\
\text { Male }\end{array}$ & $\begin{array}{c}(3) \\
\text { Female }\end{array}$ \\
\hline & $(0.000)$ & $(0.000)$ & $(0.000)$ \\
\hline Risk Willingness & $\begin{array}{l}-0.380 * * * \\
(0.002)\end{array}$ & $\begin{array}{l}-0.579 * * * \\
(0.007)\end{array}$ & $\begin{array}{l}-0.242 \\
(0.118)\end{array}$ \\
\hline $\begin{array}{l}\text { Consideration of } \\
\text { Future Consequences }\end{array}$ & $0.499 * * *$ & $0.634 * * *$ & $0.408 * * *$ \\
\hline Constant & $\begin{array}{c}(0.000) \\
36.186 * * * \\
(0.000)\end{array}$ & $\begin{array}{c}(0.000) \\
30.843^{* * *} \\
(0.000)\end{array}$ & $\begin{array}{c}(0.000) \\
40.436^{* * *} \\
(0.000)\end{array}$ \\
\hline $\begin{array}{l}\text { Observations } \\
\text { R-squared }\end{array}$ & $\begin{array}{l}1866 \\
0.154\end{array}$ & $\begin{array}{c}701 \\
0.170\end{array}$ & $\begin{array}{l}1165 \\
0.166\end{array}$ \\
\hline
\end{tabular}


Table A2-2: Total Derivatives (Table 4)

\begin{tabular}{|c|c|c|c|}
\hline VARIABLES & All Sample & Males & Females \\
\hline Gender & $\begin{array}{c}-0.007^{* * *} \\
(0.006)\end{array}$ & & \\
\hline Age & $\begin{array}{c}-0.041^{* * *} \\
(0.000)\end{array}$ & $\begin{array}{c}-0.051^{* * *} \\
(0.005)\end{array}$ & $\begin{array}{c}-0.038 * * * \\
(0.003)\end{array}$ \\
\hline Year & $\begin{array}{l}-0.001 \\
(0.880)\end{array}$ & $\begin{array}{c}0.011 \\
(0.217)\end{array}$ & $\begin{array}{l}-0.008 \\
(0.250)\end{array}$ \\
\hline Leaving Certificate & $\begin{array}{l}4.860 * * * \\
(0.000)\end{array}$ & $\begin{array}{c}5.589 * * * \\
(0.000)\end{array}$ & $\begin{array}{l}4.548 * * * \\
(0.000)\end{array}$ \\
\hline Risk Willingness & $\begin{array}{c}0.025 * * * \\
(0.008)\end{array}$ & $\begin{array}{c}0.002 \\
(0.905)\end{array}$ & $\begin{array}{c}0.033^{* * *} \\
(0.005)\end{array}$ \\
\hline $\begin{array}{l}\text { Consideration of } \\
\text { Future Consequences }\end{array}$ & $\begin{array}{c}0.010 \\
(0.550)\end{array}$ & $\begin{array}{c}0.026 \\
(0.366)\end{array}$ & $\begin{array}{c}0.001 \\
(0.972)\end{array}$ \\
\hline
\end{tabular}

$\mathrm{P}$-values in parentheses

*** $\mathrm{p}<0.01,{ }^{* *} \mathrm{p}<0.05,{ }^{*} \mathrm{p}<0.1$ 
Table A2-3: Grade Decomposition using Maximum Parental Education

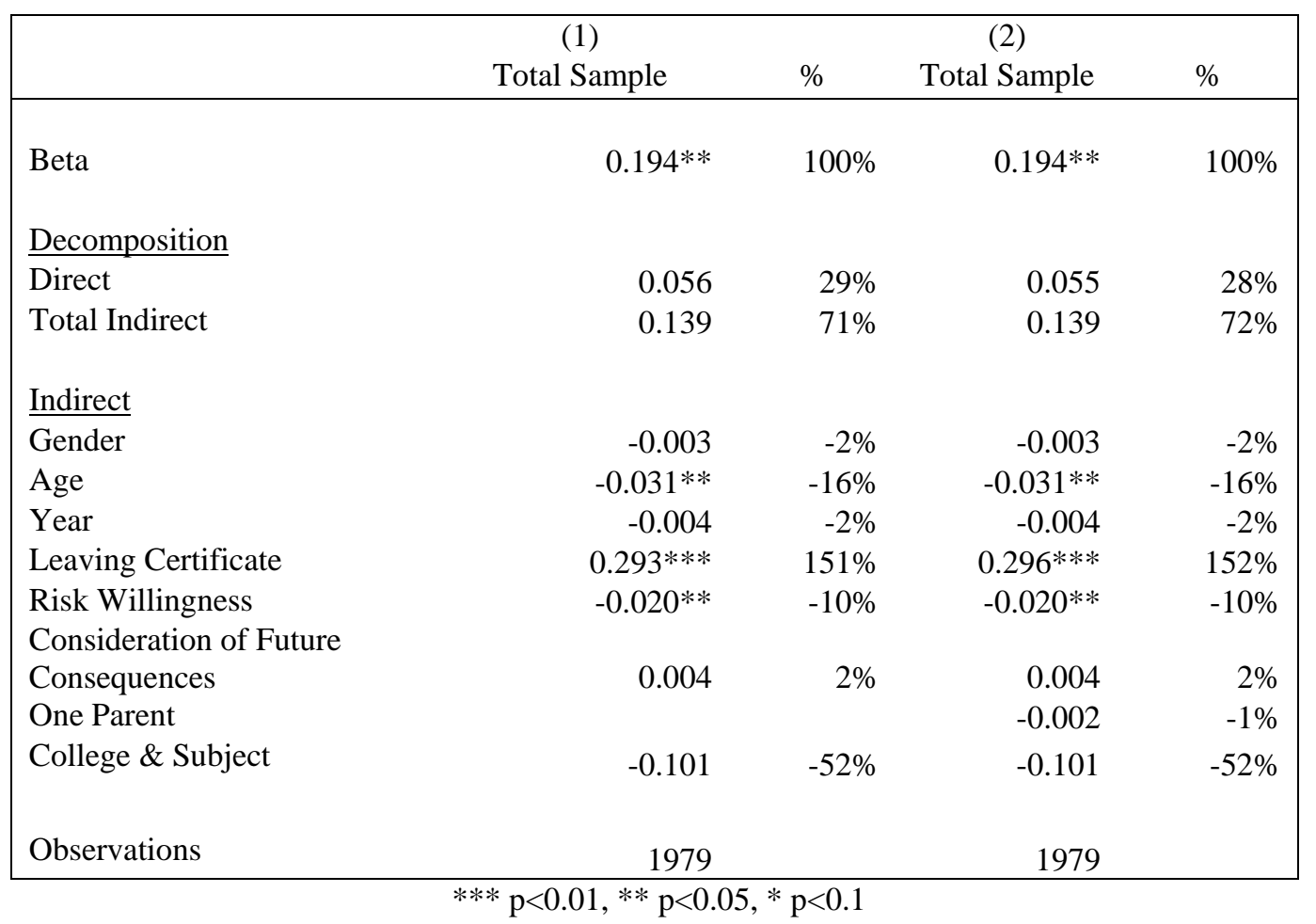

Note: This table shows the results from a number of grade decomposition. The first column estimates the decomposition for the entire sample using maximum parental education as the SES variable. The second column estimates the same model and also controls for belonging to a one parent family. Standard errors were computed using bootstrapped estimation with 2000 replications. 
Table A2-4: Partial Derivatives (Table 7)

\begin{tabular}{|c|c|c|c|}
\hline VARIABLES & $\begin{array}{c}\text { (1) } \\
\text { All Sample } \\
\end{array}$ & $\begin{array}{l}(2) \\
\text { Male } \\
\end{array}$ & $\begin{array}{c}(3) \\
\text { Female } \\
\end{array}$ \\
\hline Parental Education & $\begin{array}{c}0.526 \\
(0.994)\end{array}$ & $\begin{array}{c}9.493 \\
(0.942)\end{array}$ & $\begin{array}{l}15.127 \\
(0.858)\end{array}$ \\
\hline Gender & $\begin{array}{c}478.361^{* *} \\
(0.014)\end{array}$ & $\begin{array}{l}377.435 \\
(0.298)\end{array}$ & $\begin{array}{c}540.505^{* *} \\
(0.019)\end{array}$ \\
\hline Age & $\begin{array}{c}-2,637.962^{* * *} \\
(0.000)\end{array}$ & & \\
\hline Year & $\begin{array}{c}-2,286.869 * * * \\
(0.000)\end{array}$ & $\begin{array}{c}-2,030.799 * * * \\
(0.002)\end{array}$ & $\begin{array}{c}-2,374.615^{* * * *} \\
(0.000)\end{array}$ \\
\hline Humanities \& Arts & $\begin{array}{c}-3,761.313^{*} \\
(0.080)\end{array}$ & $\begin{array}{c}-1,272.177 \\
(0.732)\end{array}$ & $\begin{array}{c}-5,764.247^{* *} \\
(0.031)\end{array}$ \\
\hline Social Science & $\begin{array}{c}-870.942 \\
(0.703)\end{array}$ & $\begin{array}{c}1,137.898 \\
(0.783)\end{array}$ & $\begin{array}{c}-2,779.516 \\
(0.319)\end{array}$ \\
\hline Business & $\begin{array}{c}-257.183 \\
(0.908)\end{array}$ & $\begin{array}{c}2,460.644 \\
(0.512)\end{array}$ & $\begin{array}{c}-2,316.300 \\
(0.403)\end{array}$ \\
\hline Law & $\begin{array}{c}2,970.744 \\
(0.224)\end{array}$ & $\begin{array}{c}10,839.482 * * \\
(0.013)\end{array}$ & $\begin{array}{c}-1,222.456 \\
(0.682)\end{array}$ \\
\hline Science & $\begin{array}{c}-201.284 \\
(0.926)\end{array}$ & $\begin{array}{c}3,132.906 \\
(0.399)\end{array}$ & $\begin{array}{c}-2,479.146 \\
(0.360)\end{array}$ \\
\hline Maths & $\begin{array}{c}3,098.337 \\
(0.272)\end{array}$ & $\begin{array}{c}5,831.757 \\
(0.197)\end{array}$ & $\begin{array}{c}3,127.225 \\
(0.405)\end{array}$ \\
\hline Computer Science & $\begin{array}{c}818.115 \\
(0.774)\end{array}$ & $\begin{array}{c}2,140.088 \\
(0.617)\end{array}$ & $\begin{array}{c}1,470.394 \\
(0.735)\end{array}$ \\
\hline Eng/Manu/Const. & $\begin{array}{c}-494.485 \\
(0.830)\end{array}$ & $\begin{array}{c}3,049.749 \\
(0.405)\end{array}$ & $\begin{array}{c}-4,274.505 \\
(0.178)\end{array}$ \\
\hline Agri/Veterinary & $\begin{array}{c}786.602 \\
(0.813)\end{array}$ & $\begin{array}{c}2,156.934 \\
(0.726)\end{array}$ & $\begin{array}{r}294.277 \\
(0.942)\end{array}$ \\
\hline Health/Welfare & $\begin{array}{c}6,010.383^{* * * *} \\
(0.008)\end{array}$ & $\begin{array}{c}12,567.288^{* * *} \\
(0.003)\end{array}$ & $\begin{array}{c}3,137.702 \\
(0.254)\end{array}$ \\
\hline Sport/Catering/Serv. & $\begin{array}{c}-2,828.016 \\
(0.519)\end{array}$ & $\begin{array}{c}-909.859 \\
(0.902)\end{array}$ & $\begin{array}{c}-4,935.822 \\
(0.367)\end{array}$ \\
\hline Other & $\begin{array}{c}-609.337 \\
(0.807)\end{array}$ & $\begin{array}{c}2,357.871 \\
(0.593)\end{array}$ & $\begin{array}{c}-3,049.388 \\
(0.320)\end{array}$ \\
\hline UCD & $\begin{array}{c}701.485 \\
(0.500)\end{array}$ & $\begin{array}{c}1,475.104 \\
(0.460)\end{array}$ & $\begin{array}{l}129.405 \\
(0.916)\end{array}$ \\
\hline NUIM & $\begin{array}{c}-1,685.042 \\
(0.176)\end{array}$ & $\begin{array}{c}-2,234.434 \\
(0.361)\end{array}$ & $\begin{array}{c}-1,331.833 \\
(0.355)\end{array}$ \\
\hline NUIG & $\begin{array}{c}-2,392.978^{* *} \\
(0.033)\end{array}$ & $\begin{array}{c}-2,636.789 \\
(0.217)\end{array}$ & $\begin{array}{c}-2,636.828 * * \\
(0.046)\end{array}$ \\
\hline TCD & $\begin{array}{c}-1,224.420 \\
(0.257)\end{array}$ & $\begin{array}{c}-1,902.349 \\
(0.363)\end{array}$ & $\begin{array}{c}-763.848 \\
(0.546)\end{array}$ \\
\hline UL & $\begin{array}{c}-342.660 \\
(0.777)\end{array}$ & $\begin{array}{c}298.403 \\
(0.894)\end{array}$ & $\begin{array}{c}-867.489 \\
(0.551)\end{array}$ \\
\hline DCU & $\begin{array}{c}-1,142.888 \\
(0.458)\end{array}$ & $\begin{array}{c}-1,795.616 \\
(0.545)\end{array}$ & $\begin{array}{c}-535.030 \\
(0.766)\end{array}$ \\
\hline Leaving Certificate & $\begin{array}{c}25.626 * * * \\
(0.000)\end{array}$ & $\begin{array}{l}18.406^{*} \\
(0.069)\end{array}$ & $\begin{array}{c}28.355^{* * * *} \\
(0.000)\end{array}$ \\
\hline Risk Willingness & $\begin{array}{c}722.490 * * * \\
(0.001)\end{array}$ & $\begin{array}{c}876.876^{* *} \\
(0.023)\end{array}$ & $\begin{array}{c}595.401 * * \\
(0.017)\end{array}$ \\
\hline Grade & $\begin{array}{l}184.544 \\
(0.666)\end{array}$ & $\begin{array}{c}-601.145 \\
(0.442)\end{array}$ & $\begin{array}{c}596.842 \\
(0.246)\end{array}$ \\
\hline Extraversion & $\begin{array}{c}280.620^{* *} \\
(0.027)\end{array}$ & $\begin{array}{l}-67.695 \\
(0.771)\end{array}$ & $\begin{array}{c}462.415^{* * * *} \\
\quad(0.002)\end{array}$ \\
\hline $\begin{array}{l}\text { Agreeableness } \\
\text { (cont....) }\end{array}$ & $\begin{array}{c}216.556 \\
(0.145)\end{array}$ & $\begin{array}{c}274.379 \\
(0.315)\end{array}$ & $\begin{array}{l}161.418 \\
(0.368)\end{array}$ \\
\hline
\end{tabular}


Table A2-4: Partial Derivatives (Table 7) - continued

\begin{tabular}{|lccc|}
\hline \multirow{2}{*}{ VARIABLES } & $(1)$ & $(2)$ & $(3)$ \\
Conscientiousness & All Sample & Male & Female \\
Neuroticism & $218.393^{*}$ & $620.706^{* * *}$ & -18.805 \\
& $(0.099)$ & $(0.00934)$ & $(0.907)$ \\
Openness & -41.971 & -317.365 & 79.021 \\
& $(0.728)$ & $(0.163)$ & $(0.579)$ \\
Consideration of & 57.693 & 284.289 & -98.544 \\
Future Consequences & $(0.735)$ & $(0.357)$ & $(0.634)$ \\
& 99.268 & 21.261 & 138.391 \\
Constant & $(0.292)$ & $(0.903)$ & $(0.220)$ \\
& $5,139.696$ & $6,539.863$ & $3,121.932$ \\
Observations & $(0.389)$ & $(0.547)$ & $(0.666)$ \\
R-squared & 1873 & & 1215 \\
& 0.123 & P-values in parentheses & 0.132 \\
\hline
\end{tabular}


Table A2-5: Total Derivatives (Table 7 \& 9)

\begin{tabular}{|c|c|c|c|}
\hline VARIABLES & All Sample & Males & Females \\
\hline Gender & $\begin{array}{c}-0.006^{* *} \\
(0.017)\end{array}$ & & \\
\hline Age & $\begin{array}{c}-0.024^{* *} \\
(0.012)\end{array}$ & $\begin{array}{l}-0.001 \\
(0.965)\end{array}$ & $\begin{array}{c}-0.038 * * * \\
(0.001)\end{array}$ \\
\hline Year & $\begin{array}{l}-0.006 \\
(0.227)\end{array}$ & $\begin{array}{l}-0.006 \\
(0.495)\end{array}$ & $\begin{array}{l}-0.007 \\
(0.309)\end{array}$ \\
\hline Leaving Certificate & $\begin{array}{c}4.367 * * * \\
(0.000)\end{array}$ & $\begin{array}{c}3.960 * * * \\
(0.000)\end{array}$ & $\begin{array}{c}4.658 * * * \\
(0.000)\end{array}$ \\
\hline Risk Willingness & $\begin{array}{c}0.021 * * \\
(0.011)\end{array}$ & $\begin{array}{c}0.030 * * \\
(0.037)\end{array}$ & $\begin{array}{c}0.014 \\
(0.167)\end{array}$ \\
\hline $\begin{array}{l}\text { Consideration of } \\
\text { Future Consequences }\end{array}$ & -0.002 & -0.009 & 0.002 \\
\hline & $(0.918)$ & $(0.770)$ & $(0.912)$ \\
\hline Grade & $\begin{array}{c}0.011 * * * \\
(0.006)\end{array}$ & $\begin{array}{l}0.016^{* *} \\
(0.024)\end{array}$ & $\begin{array}{l}0.008^{*} \\
(0.089)\end{array}$ \\
\hline Extraversion & $\begin{array}{c}0.044 * * * \\
(0.001)\end{array}$ & $\begin{array}{c}0.048 * * \\
(0.035)\end{array}$ & $\begin{array}{c}0.047 * * * \\
(0.004)\end{array}$ \\
\hline Agreeableness & $\begin{array}{c}0.015 \\
(0.183)\end{array}$ & $\begin{array}{c}0.039 * * \\
(0.033)\end{array}$ & $\begin{array}{c}-0.007 \\
(0.575)\end{array}$ \\
\hline Conscientiousness & $\begin{array}{c}-0.039 * * * \\
(0.003)\end{array}$ & $\begin{array}{c}-0.046^{* *} \\
(0.041)\end{array}$ & $\begin{array}{c}-0.033^{* *} \\
(0.038)\end{array}$ \\
\hline Neuroticism & $\begin{array}{c}-0.034^{* *} \\
(0.014)\end{array}$ & $\begin{array}{l}-0.020 \\
(0.377)\end{array}$ & $\begin{array}{l}-0.031 * \\
(0.069)\end{array}$ \\
\hline Openness & $\begin{array}{c}0.011 \\
(0.282)\end{array}$ & $\begin{array}{c}0.018 \\
(0.307)\end{array}$ & $\begin{array}{c}0.010 \\
(0.424)\end{array}$ \\
\hline
\end{tabular}

P-values in parentheses

*** $\mathrm{p}<0.01,{ }^{* *} \mathrm{p}<0.05,{ }^{*} \mathrm{p}<0.1$ 
Table A2-6: Partial Derivatives (Table 9)

\begin{tabular}{|c|c|c|c|}
\hline VARIABLES & $\begin{array}{c}(1) \\
\text { All Sample } \\
\end{array}$ & $\begin{array}{l}(2) \\
\text { Male } \\
\end{array}$ & $\begin{array}{c}(3) \\
\text { Female } \\
\end{array}$ \\
\hline Parental Education & $\begin{array}{c}1,106.794^{* * * *} \\
(0.000)\end{array}$ & $\begin{array}{c}854.337 * \\
(0.057)\end{array}$ & $\begin{array}{c}1,267.948^{* * * *} \\
(0.000)\end{array}$ \\
\hline Gender & $\begin{array}{c}859.408 \\
(0.199)\end{array}$ & $\begin{array}{c}1,188.263 \\
(0.340)\end{array}$ & $\begin{array}{c}572.330 \\
(0.471)\end{array}$ \\
\hline Age & $\begin{array}{c}-19,713.056^{* * *} \\
(0.000)\end{array}$ & & \\
\hline Year & $\begin{array}{c}-2,231.743^{*} \\
(0.059)\end{array}$ & $\begin{array}{l}-2.241 \\
(0.999)\end{array}$ & $\begin{array}{c}-3,221.301 * * \\
(0.021)\end{array}$ \\
\hline Humanities \& Arts & $\begin{array}{c}23,805.199 * * * \\
(0.001)\end{array}$ & $\begin{array}{c}30,380.974^{* *} \\
(0.018)\end{array}$ & $\begin{array}{l}17,410.929 * \\
(0.058)\end{array}$ \\
\hline Social Science & $\begin{array}{c}33,817.793^{* * *} \\
(0.000)\end{array}$ & $\begin{array}{c}52,018.712^{* * * *} \\
(0.000)\end{array}$ & $\begin{array}{c}23,704.301^{* *} \\
(0.014)\end{array}$ \\
\hline Business & $\begin{array}{c}41,782.171^{* * *} \\
(0.000)\end{array}$ & $\begin{array}{c}50,820.220^{* * * *} \\
(0.000)\end{array}$ & $\begin{array}{c}34,184.994 * * * \\
(0.000)\end{array}$ \\
\hline Law & $\begin{array}{c}48,914.835^{* * *} \\
(0.000)\end{array}$ & $\begin{array}{c}50,215.676^{* * * *} \\
(0.001)\end{array}$ & $\begin{array}{l}44,500.157^{* * * *} \\
(0.000)\end{array}$ \\
\hline Science & $\begin{array}{c}23,380.653^{* * * *} \\
(0.002)\end{array}$ & $\begin{array}{c}27,413.417^{* *} \\
(0.032)\end{array}$ & $\begin{array}{c}17,870.623^{*} \\
(0.056)\end{array}$ \\
\hline Maths & $\begin{array}{c}34,121.058^{* * * *} \\
(0.000)\end{array}$ & $\begin{array}{c}40,595.459 * * * \\
(0.009)\end{array}$ & $\begin{array}{c}34,898.129 * * * \\
(0.00699)\end{array}$ \\
\hline Computer Science & $\begin{array}{c}44,868.569 * * * \\
(0.000)\end{array}$ & $\begin{array}{c}49,878.060^{* * *} \\
(0.001)\end{array}$ & $\begin{array}{c}40,530.598^{* * *} \\
(0.007)\end{array}$ \\
\hline Eng/Manu/Const. & $\begin{array}{c}31,036.166^{* * *} \\
(0.000)\end{array}$ & $\begin{array}{c}36,917.375^{* * *} \\
(0.003)\end{array}$ & $\begin{array}{l}29,961.765 * * * \\
(0.006)\end{array}$ \\
\hline Agri/Veterinary & $\begin{array}{c}17,611.458 \\
(0.125)\end{array}$ & $\begin{array}{c}35,018.349 * \\
(0.098)\end{array}$ & $\begin{array}{c}7,223.928 \\
(0.601)\end{array}$ \\
\hline Health/Welfare & $\begin{array}{c}27,474.360^{* * *} \\
(0.000)\end{array}$ & $\begin{array}{c}41,864.596 * * * \\
(0.004)\end{array}$ & $\begin{array}{c}19,392.826^{* * *} \\
(0.041)\end{array}$ \\
\hline Sport/Catering/Serv. & $\begin{array}{c}19,239.566 \\
(0.203)\end{array}$ & $\begin{array}{c}26,309.653 \\
(0.302)\end{array}$ & $\begin{array}{c}13,947.460 \\
(0.459)\end{array}$ \\
\hline Other & $\begin{array}{c}37,479.048^{* * *} \\
(0.000)\end{array}$ & $\begin{array}{c}38,565.874^{* *} \\
(0.011)\end{array}$ & $\begin{array}{c}33,478.694 * * * \\
(0.002)\end{array}$ \\
\hline UCD & $\begin{array}{c}5,864.503 \\
(0.102)\end{array}$ & $\begin{array}{c}3,316.940 \\
(0.629)\end{array}$ & $\begin{array}{c}6,712.807 \\
(0.111)\end{array}$ \\
\hline NUIM & $\begin{array}{c}-4,580.265 \\
(0.286)\end{array}$ & $\begin{array}{c}-8,898.197 \\
(0.290)\end{array}$ & $\begin{array}{c}-1,329.063 \\
(0.788)\end{array}$ \\
\hline NUIG & $\begin{array}{c}-1,404.510 \\
(0.716)\end{array}$ & $\begin{array}{c}2,686.592 \\
(0.714)\end{array}$ & $\begin{array}{c}-4,102.866 \\
(0.367)\end{array}$ \\
\hline TCD & $\begin{array}{c}-1,758.609 \\
(0.637)\end{array}$ & $\begin{array}{c}3,250.787 \\
(0.651)\end{array}$ & $\begin{array}{c}-3,456.179 \\
(0.427)\end{array}$ \\
\hline UL & $\begin{array}{c}-6,435.892 \\
(0.123)\end{array}$ & $\begin{array}{c}-13,418.279 * \\
(0.081)\end{array}$ & $\begin{array}{c}-1,398.331 \\
(0.780)\end{array}$ \\
\hline DCU & $\begin{array}{c}2,353.988 \\
(0.656)\end{array}$ & $\begin{array}{c}5,265.961 \\
(0.605)\end{array}$ & $\begin{array}{c}904.429 \\
(0.883)\end{array}$ \\
\hline Leaving Certificate & $\begin{array}{c}140.571^{* * * *} \\
(0.000)\end{array}$ & $\begin{array}{l}123.148^{* * * *} \\
(0.000)\end{array}$ & $\begin{array}{c}143.808^{* * * *} \\
(0.000)\end{array}$ \\
\hline Risk Willingness & $\begin{array}{c}2,739.094 * * * \\
(0.000)\end{array}$ & $\begin{array}{c}4,963.435 * * * \\
(0.000)\end{array}$ & $\begin{array}{c}1,700.373^{* *} \\
(0.046)\end{array}$ \\
\hline Grade & $\begin{array}{c}1,345.235 \\
(0.360)\end{array}$ & $\begin{array}{c}1,080.968 \\
(0.687)\end{array}$ & $\begin{array}{c}1,485.592 \\
(0.401)\end{array}$ \\
\hline Extraversion & $\begin{array}{c}1,179.038^{* * *} \\
(0.007)\end{array}$ & $\begin{array}{c}261.459 \\
(0.743)\end{array}$ & $\begin{array}{c}1,509.577^{* * * *} \\
(0.004)\end{array}$ \\
\hline $\begin{array}{l}\text { Agreeableness } \\
\text { (cont....) }\end{array}$ & $\begin{array}{c}1,151.486^{* *} \\
(0.024)\end{array}$ & $\begin{array}{l}20.927 \\
(0.982)\end{array}$ & $\begin{array}{c}1,546.760^{* *} \\
(0.012)\end{array}$ \\
\hline
\end{tabular}


Table A2-6: Partial Derivatives (Table 9) - continued

\begin{tabular}{|lccc|}
\hline \multicolumn{1}{|c}{} & $(1)$ & $(2)$ & $(3)$ \\
VARIABLES & All Sample & Male & Female \\
\hline Conscientiousness & 435.257 & 987.394 & $(0.720)$ \\
& $(0.340)$ & $(0.228)$ & $-863.861^{*}$ \\
Neuroticism & -455.747 & 31.612 & $(0.078)$ \\
& $(0.272)$ & $(0.968)$ & $1,165.869$ \\
Openness & $1,354.245^{* *}$ & $1,651.265$ & $(0.102)$ \\
& $(0.021)$ & $(0.119)$ & 408.321 \\
Consideration of & $857.823^{* * *}$ & $1,646.405^{* * *}$ & $(0.294)$ \\
Future Consequences & & & $-85,475.071^{* * *}$ \\
& $(0.008)$ & $(0.006)$ & $(0.001)$ \\
Constant & $-88,292.777^{* * *}$ & $-112,040.910^{* * *}$ & 1215 \\
& $(0.000)$ & $(0.003)$ & 0.172 \\
Observations & 1873 & 658 & \\
R-squared & 0.199 & 0.192 & \\
\hline
\end{tabular}

$\mathrm{P}$-values in parentheses

*** $\mathrm{p}<0.01, * * \mathrm{p}<0.05, * \mathrm{p}<0.1$ 
Table A2-7: Earnings Decomposition using Maximum Parental Education

\begin{tabular}{|c|c|c|c|c|c|c|c|c|}
\hline & $\begin{array}{c}(1) \\
\text { Total } \\
\text { Sample }\end{array}$ & $\%$ & $\begin{array}{c}(2) \\
\text { Total } \\
\text { Sample }\end{array}$ & $\%$ & $\begin{array}{c}(3) \\
\text { Total Sample }\end{array}$ & $\%$ & $\begin{array}{c}(4) \\
\text { Total Sample }\end{array}$ & $\%$ \\
\hline Beta & $255.469 * *$ & $100 \%$ & $255.469 * *$ & $100 \%$ & $3516.665 * * *$ & $100 \%$ & $3516.665 * * *$ & $100 \%$ \\
\hline \multicolumn{9}{|l|}{ Decomposition } \\
\hline Direct & -63.697 & $-25 \%$ & -71.541 & $-28 \%$ & $1481.818^{* * *}$ & $42 \%$ & $1475.084 * * *$ & $42 \%$ \\
\hline Total Indirect & 319.166*** & $125 \%$ & $327.010 * * *$ & $128 \%$ & $2034.846^{* * *}$ & $58 \%$ & $2041.581^{* * *}$ & $58 \%$ \\
\hline \multicolumn{9}{|l|}{$\underline{\text { Indirect }}$} \\
\hline Gender & 16.854 & $7 \%$ & 17.077 & $7 \%$ & 125.636 & $4 \%$ & 125.854 & $4 \%$ \\
\hline Age & -18.475 & $-7 \%$ & -18.314 & $-7 \%$ & -34.014 & $-1 \%$ & -33.857 & $-1 \%$ \\
\hline Year & 29.330 & $11 \%$ & 29.424 & $12 \%$ & 36.678 & $1 \%$ & 36.746 & $1 \%$ \\
\hline \multicolumn{9}{|l|}{ Leaving } \\
\hline Certificate & $192.023 * * *$ & $75 \%$ & $190.830 * * *$ & $75 \%$ & $1086.023 * * *$ & $31 \%$ & $1084.803^{* * *}$ & $31 \%$ \\
\hline Risk Willingness & $30.045 * *$ & $12 \%$ & $29.524^{* *}$ & $12 \%$ & 111.010** & $3 \%$ & $110.551^{* *}$ & $3 \%$ \\
\hline Grade & 2.869 & $1 \%$ & 2.816 & $1 \%$ & 18.814 & $1 \%$ & 18.765 & $1 \%$ \\
\hline Extraversion & $32.588 * *$ & $13 \%$ & $31.818 * *$ & $12 \%$ & $111.722^{* *}$ & $3 \%$ & $111.074 * *$ & $3 \%$ \\
\hline Agreeableness & 3.761 & $1 \%$ & 3.995 & $2 \%$ & 30.042 & $1 \%$ & 30.261 & $1 \%$ \\
\hline Conscientiousness & -14.315 & $-6 \%$ & -14.355 & $-6 \%$ & -18.335 & $-1 \%$ & -18.362 & $-1 \%$ \\
\hline Neuroticism & 2.553 & $1 \%$ & 2.854 & $1 \%$ & 25.550 & $1 \%$ & 25.811 & $1 \%$ \\
\hline Openness & -0.334 & $0 \%$ & -0.131 & $0 \%$ & 20.565 & $1 \%$ & 20.736 & $1 \%$ \\
\hline \multicolumn{9}{|l|}{$\begin{array}{l}\text { Consideration of } \\
\text { Future }\end{array}$} \\
\hline Consequences & -0.136 & $0 \%$ & -0.126 & $0 \%$ & -1.863 & $0 \%$ & -1.854 & $0 \%$ \\
\hline One Parent & & & 9.036 & $4 \%$ & & & 7.836 & $0 \%$ \\
\hline College \& Subject & 42.402 & $17 \%$ & 51.598 & $20 \%$ & 523.019 & $15 \%$ & 531.054 & $15 \%$ \\
\hline Observations & 1972 & & 1972 & & 1971 & & 1971 & \\
\hline
\end{tabular}

Note: This table shows the results from a number of earnings expectations decomposition. The first column estimates the decomposition of first salary expectations for the entire sample using maximum parental education as the SES variable. The second column estimates the same model and also controls for belonging to a one parent family. The $3^{\text {rd }}$ and $4^{\text {th }}$ columns decompose maximum salary expectations. Standard errors were computed using bootstrapped estimation with 2000 replications. 


\section{Appendix 3}

Table A3-1: Grade Decomposition excluding Anticipated Grades

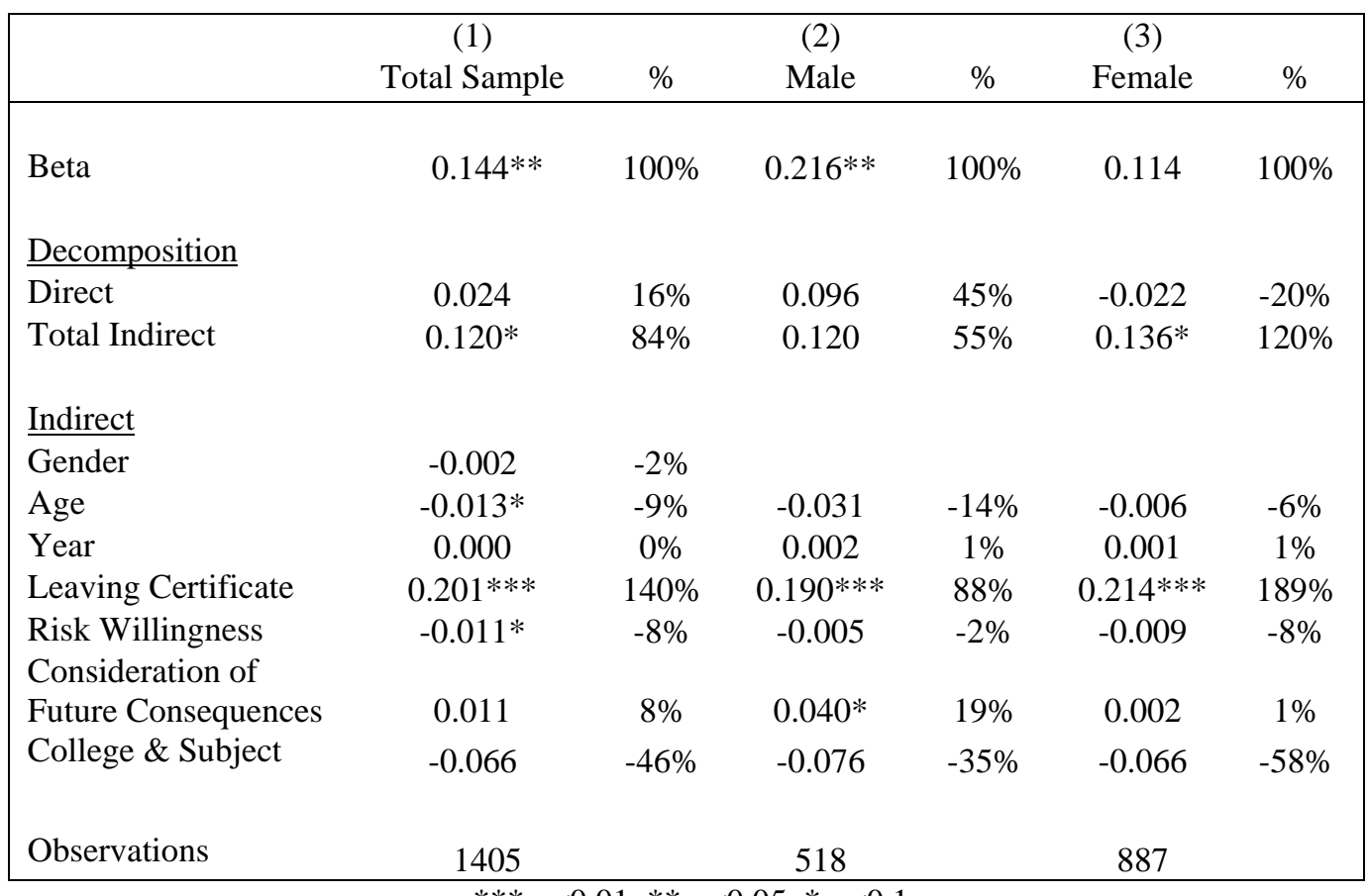

Note: This table shows the results from a number of grade decompositions. Only students who reported realised grades were included in this analysis. The first column estimates the decomposition for the entire sample. The second column estimates the same model for male students only and the final column estimates the model for female students only. Standard errors were computed using bootstrapped estimation with 2000 replications. 